\title{
An Acetal Acylation Methodology for Producing Diversity of Trihalomethyl- 1,3-dielectrophiles and 1,2-Azole Derivatives
}

\author{
Valéria D. O. Bareño, ${ }^{a}$ Daiane S. Santos, ${ }^{a}$ Leandro M. Frigo,${ }^{b}$ Debora L. de Mello, ${ }^{b}$ \\ Juliana L. Malavolta, ${ }^{b}$ Rogerio F. Blanco, ${ }^{b}$ Lucas Pizzuti, ${ }^{c}$ Darlene C. Flores ${ }^{a}$ and \\ Alex F. C. Flores ${ }^{\circledR} *, a$ \\ ${ }^{a}$ Escola de Química e Alimentos, Universidade Federal do Rio Grande, \\ 96203-900 Rio Grande-RS, Brazil \\ ${ }^{b}$ Departamento de Química, Universidade Federal de Santa Maria, \\ 97105-900 Santa Maria-RS, Brazil \\ ${ }^{c}$ Faculdade de Ciências Exatas e Tecnologia, Universidade Federal da Grande Dourados, \\ 79804-970 Dourados-MS, Brazil
}

\begin{abstract}
A series of functionalized 1,1,1-trihalo-4-methoxy-3-alken-2-ones $\left[\mathrm{CX}_{3} \mathrm{C}(\mathrm{O}) \mathrm{CR}^{1}=\mathrm{CROMe}\right.$, where $\mathrm{X}=\mathrm{F}$ or $\mathrm{Cl}$; $\mathrm{R}=n$-heptyl, $n$-octyl, $n$-nonyl, $n$-decyl, $n$-undecyl, $n$-tridecyl, $\left(\mathrm{CH}_{2}\right)_{2} \mathrm{CH}=\mathrm{C}(\mathrm{Me})_{2}$, $\left(\mathrm{CH}_{2}\right)_{2} \mathrm{Ph},\left(\mathrm{CH}_{2}\right)_{2}-\left(4-\mathrm{HOC}_{6} \mathrm{H}_{4}\right),\left(\mathrm{CH}_{2}\right)_{2}-\left(4-\mathrm{MeOC}_{6} \mathrm{H}_{4}\right),\left(\mathrm{CH}_{2}\right)_{2} \mathrm{CO}_{2} \mathrm{Me},\left(\mathrm{CH}_{2}\right)_{3} \mathrm{CO}_{2} \mathrm{Me}, \mathrm{CH}(\mathrm{SMe}) \mathrm{CH}_{3}$, $\mathrm{CH}_{2}\left(2-\mathrm{MeOC}_{6} \mathrm{H}_{4}\right)$, and $\mathrm{R}^{1}=\mathrm{H}$, and $\mathrm{R}=\mathrm{H}$ and $\mathrm{R}^{1}=n$-decyl] were synthesized from respective alkyl methyl ketones or aldehyde via acetal acylation using trifluoroacetic anhydride and trichloroacetyl chloride. 1,1,1-Trihalo-4-methoxy-3-alken-2-ones with acid-compatible substituents were easily hydrolyzed to respective trihalomethyl-1,3-diketones. The 1,1,1-trihalo-4-methoxy-3-alken-2-ones and/or respective trihalomethyl-1,3-diketones were reacted regiospecifically with hydroxylamine hydrochloride, leading to isoxazole derivatives, and with hydrazines, leading to respective $1 H$-pyrazole derivatives. The structures of all compounds were assigned based on nuclear magnetic resonance (NMR) and mass spectrometric data. This method represents an efficient pathway for the regioselective trihaloacetylation of asymmetrically substituted alkyl methyl ketones and highly self-condensing aldehydes. Moreover, this approach allows the introduction of biologically recognizable moieties, such as those from levulinic acid, sulcatone (prenyl), benzylacetone, anisylacetone, and raspberry ketone, as synthetic molecular targets.
\end{abstract}

Keywords: organic chemistry: methodology and reactions, trihalomethyl-1,3-diketones, nitrogen heterocycles, trihalomethylazoles, $1 H$-pyrazolecarboxylates

\section{Introduction}

1,1,1-Trihalo-4-alkoxy-3-alken-2-ones have been used as important regioselective heterocycle precursors. ${ }^{1,2}$ These compounds can be used to prepare a wide variety of trihalomethyl-substituted heterocyclic systems and other useful compounds. ${ }^{3,4}$ Perfluoroacylation, including trifluoroacetylation reactions, of the acetone and asymmetrically substituted, one-enolizable-site ketones with esters is of fundamental importance in organic synthesis. ${ }^{5-7} 1,3$-Diketones products have long been widely employed as effective chelating reagents and heterocyclic precursors. ${ }^{8-11}$ Fluorinated 1,3-diketones are currently

*e-mail: alex.fcf.furg@gmail.com receiving considerable attention as chelating reagents for transition metals as well as lanthanides and actinides. ${ }^{12-17}$ Metal-organic chemical vapor deposition (MOCVD) from volatile fluorinated $\beta$-diketonate precursors is widely used to produce nanostructure and luminescent materials used in microelectronics based on transition metals. ${ }^{18-20}$ They are the most employed precursors for fluorinate $N$-heterocycles such as pyrazoles ${ }^{21}$ isoxazoles,${ }^{22}$ pyrimidines, ${ }^{23}$ and quinolones. ${ }^{24}$ Claisen condensation, the most used method to obtain these precursors, is very efficient when using symmetrical ketones or ketones with only one enolizable site..$^{25-28}$ Figure 1 shows some of the more commonly used trifluoromethyl-1,3-diketones in metal coordination studies and heterocyclic synthesis. The deprotonation of asymmetrical ketones results 
in a less-substituted enolate by irreversible kinetic control, whereas those reactions under thermodynamic control usually yield the more substituted product. In more favorable cases, one regioisomer can greatly predominate the equilibrium mixture, but often the equilibrium constant is not sufficiently high to achieve an acceptable regioselectivity. Furthermore, even if one prepares a regiodefined enolate, problems may occur with proton-transfer isomerization. ${ }^{29,30}$ On the other hand, the trichloromethyl group has attracted the attention of new material researchers in different fields of chemistry. For example, in the course of screening fungal extracts for new metabolites that induce morphological and physiological differentiation in human HL-60 cells, Becker and Anke ${ }^{31}$ isolated and characterized pinicoloform, attributed as (2Z, 5Z, 7E)-1,1,1-trichloro-2-hydroxy-2,5,7-undecatrien4-one, from fermentations of Risinicium pinicola (Figure 2). Synthetic compounds containing a trichloromethyl group have demonstrated high relevance as biological agents and synthetic intermediates; among them, apcin derivatives (Figure 2) have the ability to block mitotic exit, inducing tumor cell death. ${ }^{32}$ Penclomedine, 3,5-dichloro2,4-dimethoxy-6-trichloromethyl pyridine (Figure 2) is presently in clinical trials by the United States National Institutes of Health for treating patients with unspecified solid tumors and lymphoma. ${ }^{33}$

Furthermore, some specimens of sponge (Dysidea herbacea) contain 5,5,5-trichloroleucine derivatives, including dysidenin, barbamide, herbacic acid, and herbamide (Figure 2). Interest in natural products that contain the trichloromethyl group found in sponges has been stimulated by biosynthetic observations that the pro- $S$ methyl group of leucine, or an unidentified leucine derivative, is the origin of the trichloromethyl group in a compound produced by the marine cyanobacterium Lyngbya majuscule. This is important in the context that two independent groups have provided evidence that another cyanobacterium, the symbiotic Oscillatoria spongeliae, which lives in association with $D$. herbacea, is the source of chlorinated metabolites extracted from D. herbacea. ${ }^{34,35}$<smiles>CC(=O)CC(F)(F)F</smiles><smiles>CC(C)(C)C(=O)CC(=O)C(F)(F)F</smiles><smiles>O=C(CC(=O)C(F)(F)F)C(F)(F)F</smiles><smiles>O=C(CC(=O)C(F)(F)F)C(F)(F)F</smiles><smiles>O=C(CC(=O)C(F)(F)F)c1cccs1</smiles><smiles>O=C(CC(=O)C(F)(F)F)c1ccc2ccccc2c1</smiles><smiles>O=C(CC(=O)C(F)(F)F)c1ccccc1</smiles><smiles>O=C(CC(=O)C(F)(F)F)c1cccnc1</smiles>

$$
\mathrm{G}=\mathrm{H}, \mathrm{F}, \mathrm{Cl}, \mathrm{Br}, \mathrm{OH}, \mathrm{Me}, \mathrm{SO}_{3} \mathrm{H}, \mathrm{Ph}
$$

2,3 or 4-pyridinyl

Figure 1. Trifluoromethyl containing $\beta$-diketones broadly used as metal ligands.<smiles>CC(NC(=O)C(CC(C)C(Cl)(Cl)Cl)N(C)C(=O)CC(C)(Cl)Cl)c1nccs1</smiles><smiles>CC(C)CC=CC=CC(=O)NC(c1nccs1)C(C)C</smiles><smiles>CO/C(=C/C(=O)N(C)C(Cc1ccccc1)c1nccs1)CC(C)C</smiles><smiles>CC(CC(C(=O)O)N(C)C(=O)C=CCC(C)C(Cl)(Cl)Cl)C(C)(Cl)Cl</smiles>

Herbacic acid<smiles>CCC/C=C/C=C\C(=O)C=C(O)C(Cl)(Cl)Cl</smiles>

Pinicoloform<smiles>Cc1ncc([N+](=O)[O-])n1CCOC(=O)NC(Nc1ncccn1)C(Cl)(Cl)Cl</smiles>

Apcin<smiles>COc1nc(C(F)(F)Cl)c(Cl)c(OC)c1Cl</smiles>

Penclomedine

Figure 2. Natural and synthetic trichloromethyl-substituted substances. 
The trichloromethyl group also has attracted attention in crystallographic studies, as well, due to potential sigma effects on chlorine halogen bonding. ${ }^{36}$ Therefore, the acylation process of acetals is important, particularly for trichloromethyl derivatives, because of the wide scope of the method and consequent diversification of 1,3-dielectrophilic precursors. To the best of our knowledge, acylation of acetals is the only method to date that has been useful to systematically obtain trichloromethyl-substituted 1,3-dielectrophiles. ${ }^{37,38}$

\section{Results and Discussion}

\section{Acetal acylation methodology}

Acetal synthesis was conducted using an adaptation of the Wohl method. ${ }^{37}$ Ketones 1a-j were reacted with one mol-equivalent of trimethyl orthoformate under p-toluenesulfonic acid catalysis; after 8 to $24 \mathrm{~h}$, the acid was neutralized with $\mathrm{K}_{2} \mathrm{CO}_{3}$. For levulinic acid (1m) and 5-oxohexanoic acid (1n), reacting one mol-equivalent of trimethyl orthoformate led to methyl 4-oxopentanoate and methyl 5-oxohexanoate, respectively, demonstrating that esterification occurred before the ketalization. To perform esterification and ketalization, 2.5 mol-equivalents of trimethyl orthoformate were added and the mixture was maintained without stirring for $48 \mathrm{~h}$. Distilled acetals 2a-n were reacted with two mol-equivalents of trifluoroacetyl anhydride or trichloroacetyl chloride in a pyridine/ $\mathrm{CHCl}_{3}$ mixture at -5 to $10{ }^{\circ} \mathrm{C}$, leading to kinetic enol ether, an unsubstituted enol, via O-acylation (Scheme 1). According to the literature and our own experience, this enol ether derived from asymmetrically substituted dimethoxy acetals is readily acylated, through the lower activation energy intermediary, favored by steric factors. Although theoretically there is a higher concentration of thermodynamic enol ether, its acylation requires a higher activation energy, probably due to steric hindrance from the substituent on the $\beta$-carbon. Our results demonstrate that the presence of the substituents in the enol ether precursor makes it difficult to form the $\mathrm{C}-\mathrm{C}$ bond to obtain the enolone push-pull system; thus, experimentally, we can control the regioselectivity by controlling the reaction temperature of trihaloacetylation. ${ }^{38}$

Using this method, it was possible to obtain a large and diversified series of 1,3-dielectrophiles, as 1,1,1-trialo4-methoxy-3-alken-2-ones $\mathbf{2 , 3 a - n}$. In the process of acylating the dimethoxy acetal from raspberry ketone (1i), the hydroxyl substituent of the aromatic ring competed for the acylating agent, making it necessary to increase the quantity of this reagent for complete $\mathrm{C}$-acylation of the enol ether; the proper stoichiometry was 1:3.5 between dimethoxy ketal $\mathbf{2} \mathbf{i}$ and trifluoroacetic anhydride. The synthesis and reactivity of the acetal precursor is key to the successful application of this method; for example, the presence of only one $\alpha$-halogen substituent in the starting ketone facilitates the formation of the ketal precursor, but dramatically reduces its reactivity for enol ether formation. Thus, even when reacting the 1-chloro-2,2-dimethoxypropane and 1,1,1-trifluoro2,2-dimethoxypropane with trichloroacetyl chloride for $24 \mathrm{~h}$ at toluene reflux temperature, it does not form any detectable amount of trichloroacetylation product, indicating that intermediate reactive enol ethers do not form during the process (Scheme 2). In addition, no acylated products were obtained in the acetal acylation reaction starting from dimethoxy acetals derived from 2-acetylpyrrol, 2-acetylpyridine, 3-acetylpyridine,

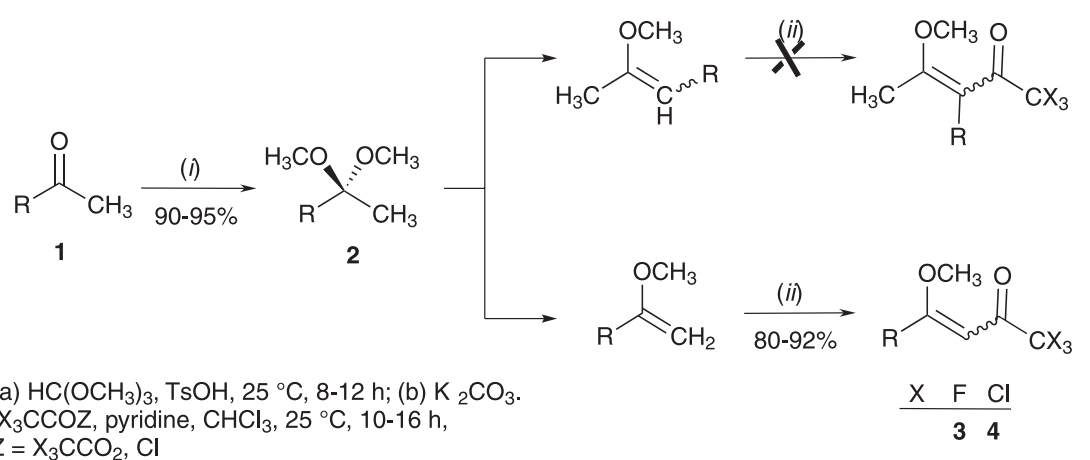

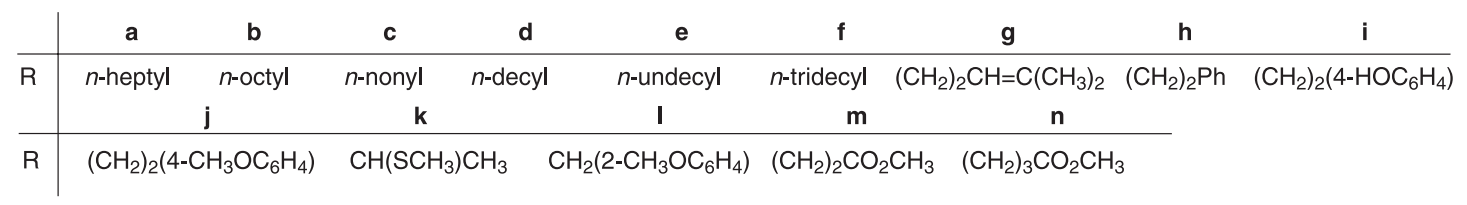

Scheme 1. Successful acetal acylation method. 


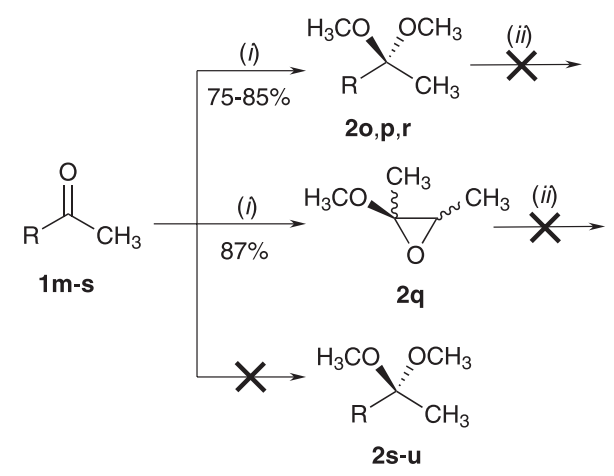

(i) (a) $\mathrm{HC}\left(\mathrm{OCH}_{3}\right)_{3}, \mathrm{TsOH}, 25^{\circ} \mathrm{C}, 8-12 \mathrm{~h}$; (b) $\mathrm{K}_{2} \mathrm{CO}_{3}$.

(ii) $\mathrm{X}_{3} \mathrm{CCOZ}$, pyridine, toluene, $110^{\circ} \mathrm{C}, 24 \mathrm{~h}, \mathrm{Z}=\mathrm{X}_{3} \mathrm{CO}_{2}, \mathrm{Cl}$

\begin{tabular}{c|ccccccc} 
& $\mathbf{0}$ & $\mathbf{p}$ & $\mathbf{q}$ & $\mathbf{r}$ & $\mathbf{s}$ & $\mathbf{t}$ & $\mathbf{u}$ \\
\hline $\mathrm{R}$ & $\mathrm{CH}_{2} \mathrm{Cl}$ & $\mathrm{CF}_{3}$ & $\mathrm{CHOHCH}_{3}$ & pyrrol-2-yl & pyridin-2-yl & pyridin-3-yl & pyridin-4-yl
\end{tabular}

Scheme 2. Limitations of the acetal acylation method.

and 4-acetylpyridine. Furthermore, the reaction of hydroxybutanone and trimethyl orthoformate produced 2-methoxy-2-methyloxirane (2q), which was unreactive in trichloroacylation medium under toluene reflux (Scheme 2). This demonstrates the complementarity between the acylation methods for some substrates since, for example, the 1,1,1-trifluoro-4-(pyridinyl)-butan-2,4-dione derivatives are easily obtained following the Claisen method. ${ }^{39,40}$

The acylation of acetals is particularly important in the case of trichloromethyl-substituted derivatives because of the scarce information available in the literature on the diversification of methods for the production of 1,3-dielectrophilic precursors containing this group. That is why we have concentrated our efforts on these in this study and have previously disclosed some individual results now discussed in this report. ${ }^{38,41}$ Therefore, if the ketal precursor is formed and isolated in sufficient amounts, it is also possible to vary the trihaloacetylating agent, as demonstrated using chlorodifluoroacetic anhydride for the acylation of methyl 4,4-dimethoxypentanoate (Scheme 3).

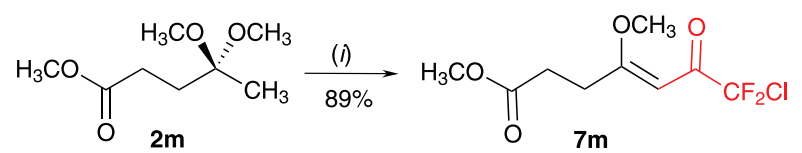

(I) $\left(\mathrm{ClF}_{2} \mathrm{CCO}\right)_{2} \mathrm{O}$, pyridine, $\mathrm{CHCl}_{3}, 25^{\circ} \mathrm{C}, 16 \mathrm{~h}$

Scheme 3. Synthesis of methyl 7-chloro-7,7-difluoro-4-methoxy-6-oxo4-heptenoate (5m).

On the other hand, Claisen condensation of aldehyde precursors has not been reported in the literature as far as we have been able to confirm; in fact, auto-condensation between aldehydes in basic medium, or aldol condensation, competes with and is preferential over acylation with an ester. ${ }^{42,43}$ In this case, acetal acylation with trihaloacetylating agents is also an attractive alternative. Obtaining acetals from aldehydes is preferred over obtaining them from ketones. In addition, for steric reasons in the acylated product, ${ }^{44,45}$ it allows the use of triethyl orthoformate instead of the more expensive trimethyl orthoformate. Therefore, we reacted lauric aldehyde and triethyl orthoformate under tosylic acid (TsOH) catalysis to obtain 1,1-diethoxydodecane. This aldehyde-derived precursor was reacted with two molar equivalents of trifluoroacetic anhydride in chloroformpyridine solution at $50{ }^{\circ} \mathrm{C}$. After $24 \mathrm{~h}$ under stirring, the consumption of all precursor acetal was observed and the reaction was quenched. The product obtained was attributed as 3-(ethoxymethylene)-1,1,1-trifluorotridecan-2-one. In addition, with this precursor, acylation was performed with chlorodifluoroacetic anhydride in chloroform-pyridine solution, leading to 1-chloro-3-(ethoxymethylene)1,1-difluorotridecan-2-one (Scheme 4).

As discussed above, the results obtained from 1,1-diethoxydodecane demonstrate that the substituent in the $\beta$-carbon in the enol ether system made the acylation process difficult, leading to a longer reaction time (24-36 h) and making it necessary to heat the solution after adding all the acylating agent. Experimentally, when using volatile trifluoroacetic anhydride as the acylating agent, it is necessary for the cooled reflux system to be very efficient and closed. From a mechanistic point of view, this indicates difficulty forming the $\mathrm{C}-\mathrm{C}$ bond by steric-electronic factors. This was probably due to the alkyl substituent at the $\alpha$-carbonyl carbon, which may have complicated the ideal geometric alignment between the electronic push-pull $\pi$ orbital system in the enol ether and the acylating agent, thereby increasing the activation energy required to achieve the transition state for the acylated ether enol product. ${ }^{44}$ 


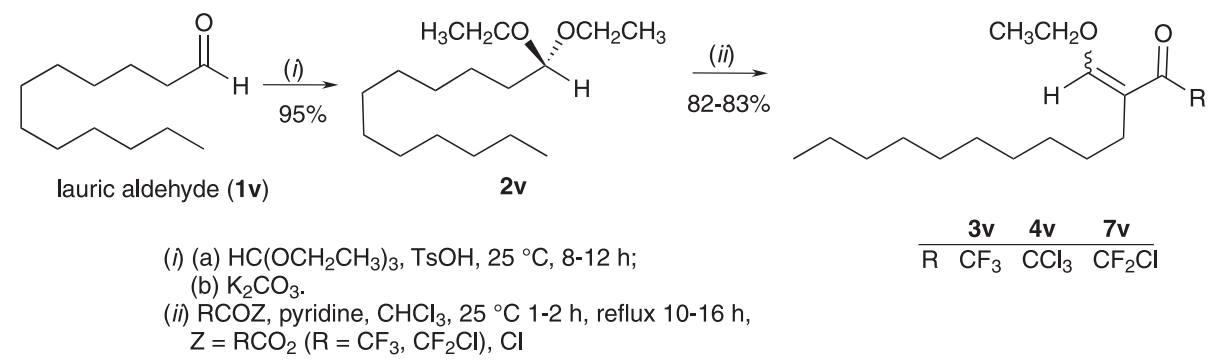

Scheme 4. Acetal acylation applied to 1,1-diethoxydodecane.

Hydrolysis of 1,1,1-trihalo-4-methoxyalk-3-en-2-ones

Keeping in mind the possibility of diversifying trihalomethyl- $\beta$-diketones via the hydrolysis of 4-alkoxy1,1,1-trihaloalk-3-en-2-ones ${ }^{46}$ presenting an alternative to the acylation of enolates with perfluorinated esters, we proceeded in two ways to obtain the respective trihalomethyl-1,3-diketones from the hydrolysis of the series of new 1,1,1-trihalo-4-methoxyalk-3-en-2-ones. First, we conducted one-pot reactions to acylate the acetals and isolate 4-alkoxy-1,1,1-trihaloalk-3-en-2-one, which was then reacted with sulfuric acid solution; acetal acylation was continued and then subsequent hydrolysis of 1,1,1-trihalo-4-methoxyalk-3-en-2-one with sulfuric acid solution was carried out (Scheme 5). Hydrolysis was performed in 1 to $3 \mathrm{~mol} \mathrm{~L}^{-1}$ sulfuric acid solution for $2 \mathrm{~h}$ with stirring under a temperature between 25 to $100{ }^{\circ} \mathrm{C}$. Diketones $\mathbf{5 h}-\mathbf{k}$ were obtained as yellow to reddish oil (see Experimental section). The results demonstrated the viability of acid hydrolysis of 1,1,1-trihalo-4-methoxyalk3 -en-2-ones with small alkyl chains to obtain the respective trihalomethyl- $\beta$-diketones; however, for 1,1,1-trihalo4-methoxyalk-3-en-2-ones obtained from fatty ketone precursors, this process does not work well. The low solubility of 1,1,1-trihalo-4-methoxyalk-3-en-2-ones 3,4a-f in aqueous acid medium probably explains the difficulty of complete conversion to the respective trihalomethyl$\beta$-diketones. As previously reported for 1,1,1-trichloro4-methoxyalk-3-en-2-ones 4a-f, ${ }^{38}$ one-pot acylation and hydrolysis in acid medium only produced a mixture of 1,1,1-trichloro-4-methoxyalk-3-en-2-one and the respective trichloromethyl- $\beta$-diketone in different proportions depending on the precursor.

Attempts to hydrolyze the isolated 1,1,1-trifluoro(chloro)4-methoxyalk-3-en-2-ones 3,4a-g were not successful even under conditions using acetonitrile to homogenize the reaction medium. Table 1 shows the reaction media used in the attempt to obtain the 1,1,1-trifluoro(chloro) undecan-2,4-dione derivatives 5,6a from 1,1,1-trihalo4-methoxyundec-3-en-2-ones 3,4a. These reaction media worked well for phenethyl-like derivatives $\mathbf{3 , 4 h}-\mathbf{j}$ and for the derivatives substituted with the thiomethyl group $\mathbf{3 , 4 k}$. For strongly acid-sensitive functional groups containing 1,1,1-trihalo-4-methoxyalk-3-en-2-ones $(\mathbf{3}, \mathbf{4 g}, \mathbf{m}, \mathbf{n})$, this process was not successful, forming in general, polymeric products without reproducibility. It is worth mentioning that one-pot hydrolysis of methyl 8,8,8-trifluoro5-methoxy-7-oxooct-5-enoate (3n) obtained 3-(4-oxo2,6-bis(trifluoromethyl)-4H-pyran-3-yl) propanoic acid, derived from condensation between the hydrolyzed product, 8,8,8-trifluoro-5,7-dioxooctanoic acid, and the methyl trifluoroacetate present in the reaction medium (Scheme 6). ${ }^{47}$

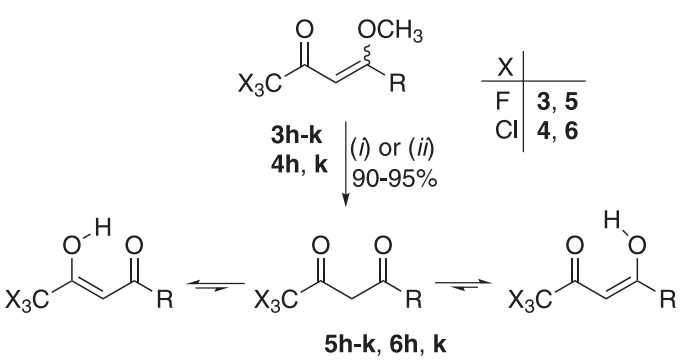

(I) $1 \mathrm{~mol} \mathrm{~L}^{-1} \mathrm{H}_{2} \mathrm{SO}_{4}, 50-100{ }^{\circ} \mathrm{C}, 6 \mathrm{~h}$ over pure precursor

(ii) $1 \mathrm{~mol} \mathrm{~L}^{-1} \mathrm{H}_{2} \mathrm{SO}_{4}, 50-100^{\circ} \mathrm{C}, 6 \mathrm{~h}$ in $\mathrm{CHCl}_{3} / \mathrm{CF}_{3} \mathrm{COO}^{-} \mathrm{PyH}^{+} / \mathrm{CF}_{3} \mathrm{CO}_{2} \mathrm{CH}_{3}$

\begin{tabular}{c|cccc} 
& $\mathbf{h}$ & $\mathbf{i}$ & $\mathbf{j}$ & $\mathbf{k}$ \\
\hline $\mathbf{R}$ & $\left(\mathrm{CH}_{2}\right)_{2} \mathrm{Ph}$ & $\left(\mathrm{CH}_{2}\right)_{2}\left(4-\mathrm{HOC}_{6} \mathrm{H}_{4}\right)$ & $\left(\mathrm{CH}_{2}\right)_{2}\left(4-\mathrm{CH}_{3} \mathrm{OC}_{6} \mathrm{H}_{4}\right)$ & $\mathrm{CH}\left(\mathrm{SCH}_{3}\right) \mathrm{CH}_{3}$
\end{tabular}

Scheme 5. Hydrolysis of 1,1,1-trifluoro-4-methoxyalk-3-en-2-ones. 
Table 1. Hydrolysis methodologies tested for production of 1,1,1-trifluoro(chloro)undecan-2,4-dione derivatives and 1,1,1-trifluoro(chloro)-6-phenylhexan2,4-dione

\begin{tabular}{|c|c|c|c|c|}
\hline entry & Precursor & Methodology & Product & Yield / \% \\
\hline $1^{\mathrm{a}}$ & $3 \mathbf{a}^{\mathrm{b}}$ & $20 \mathrm{~mL} 1 \mathrm{~mol} \mathrm{~L}^{-1} \mathrm{H}_{2} \mathrm{SO}_{4}, 25$ to $100^{\circ} \mathrm{C}$ & $3 a$ & - \\
\hline 2 & $3 a^{b}$ & $20 \mathrm{~mL} 1 \mathrm{~mol} \mathrm{~L}^{-1} \mathrm{H}_{2} \mathrm{SO}_{4}, \mathrm{CH}_{3} \mathrm{CN}, 100^{\circ} \mathrm{C}$ & 3a & - \\
\hline $3^{\mathrm{a}}$ & 3a & $20 \mathrm{~mL} 1 \mathrm{~mol} \mathrm{~L}^{-1} \mathrm{H}_{2} \mathrm{SO}_{4}, 25 \%(\mathrm{~m} / \mathrm{v}) \mathrm{PyH}^{+} \mathrm{CF}_{3} \mathrm{CO}_{2}^{-}, 100{ }^{\circ} \mathrm{C}$ & 3a & - \\
\hline $4^{\mathrm{a}}$ & 3a & $20 \mathrm{~mL} 5 \mathrm{~mol} \mathrm{~L}^{-1} \mathrm{H}_{2} \mathrm{SO}_{4}, 25 \%(\mathrm{~m} / \mathrm{v}) \mathrm{PyH}^{+} \mathrm{CF}_{3} \mathrm{CO}_{2}^{-}, 100{ }^{\circ} \mathrm{C}$ & $\mathbf{3 a}+\mathbf{5 a}(2: 1)$ & 87 \\
\hline 5 & $4 a^{b}$ & 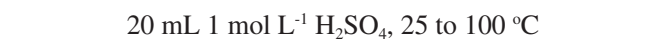 & $4 \mathbf{a}+\mathbf{6 a}(2: 1)$ & 92 \\
\hline 6 & $4 a^{b}$ & $20 \mathrm{~mL} 1 \mathrm{~mol} \mathrm{~L}^{-1} \mathrm{H}_{2} \mathrm{SO}_{4}, \mathrm{CH}_{3} \mathrm{CN}, 100^{\circ} \mathrm{C}$ & $4 a$ & - \\
\hline $7^{\mathrm{a}}$ & $4 a$ & $20 \mathrm{~mL} 5 \mathrm{~mol} \mathrm{~L}^{-1} \mathrm{H}_{2} \mathrm{SO}_{4}, 25 \%(\mathrm{~m} / \mathrm{v}) \mathrm{PyH}^{+} \mathrm{CF}_{3} \mathrm{CO}_{2}^{-}, 100^{\circ} \mathrm{C}$ & $4 \mathbf{a}+\mathbf{6 a}(1: 1)$ & - \\
\hline 8 & $3 \mathrm{~h}$ & $20 \mathrm{~mL} 1 \mathrm{~mol} \mathrm{~L}^{-1} \mathrm{H}_{2} \mathrm{SO}_{4}, 25$ to $100{ }^{\circ} \mathrm{C}$ & $5 \mathbf{h}$ & 95 \\
\hline 9 & $3 \mathrm{~h}$ & $20 \mathrm{~mL} 1 \mathrm{~mol} \mathrm{~L}^{-1} \mathrm{H}_{2} \mathrm{SO}_{4}, \mathrm{CH}_{3} \mathrm{CN}, 100{ }^{\circ} \mathrm{C}$ & $5 \mathrm{~h}$ & 92 \\
\hline 10 & $4 h$ & 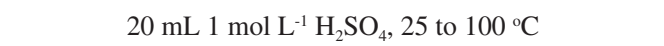 & $6 \mathrm{~h}$ & 95 \\
\hline
\end{tabular}

${ }^{\mathrm{a} O n e-p o t ~ p r o c e d u r e ; ~ b a f t e r ~ i s o l a t i o n ~ o f ~ o i l y ~ p r e c u r s o r ~} \mathbf{3 a}$ or $\mathbf{4 a}$.

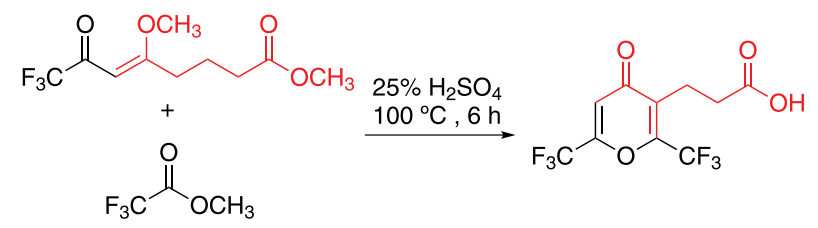

Scheme 6. Condensation during hydrolysis.

${ }^{1} \mathrm{H},{ }^{13} \mathrm{C}$, and ${ }^{19} \mathrm{~F}$ nuclear magnetic resonance (NMR) attribution

The molecular structures of the alkoxy alkenones were characterized based on NMR spectroscopy and mass spectrometry (MS) data. The electron impact ionization (EI) MS or exact mass recorded by high-resolution measurements as well as the signal pattern of NMR spectra confirmed the products obtained. In the case of trifluoroacylated ketones, the 1,1,1-trifluoro-4-methoxyalk3-en-2-ones 3a-n, the ${ }^{1} \mathrm{H}$ NMR spectra showed common characteristics including singlet signals from vinylic $\mathrm{H}-3$ (H-5 for ester 3m, and H-6 for ester 3n) at $\delta 5.6$ to $5.7 \mathrm{ppm}$ and the methoxy group at $\delta 3.78-3.79 \mathrm{ppm}$; other signals were due to alkyl from the starting ketone. The ${ }^{13} \mathrm{C}$ NMR spectra included signals from methoxyenone carbons $\mathrm{C}-1$ to $\mathrm{C}-4(\mathrm{C}-4$ to $\mathrm{C}-7$ to ester $3 \mathrm{~m}$, and $\mathrm{C}-5$ to $\mathrm{C}-8$ to ester 3n), and a signal from the methoxy group. C-1 and C-2 appeared as quartets at $\delta 116-117 \mathrm{ppm}$ with ${ }^{1} J_{\mathrm{CF}} 292 \mathrm{~Hz}$, and $\delta 178-179$ ppm with ${ }^{2} J_{\mathrm{CF}} 34 \mathrm{~Hz}$, respectively; C-3 appeared at $\delta 91-92 \mathrm{ppm}$; and C-4 appeared at $\delta 182$ to $185 \mathrm{ppm}$, with spectra obtained for 1,1,1-trifluoro-4-methoxy-8-methyl non-3,7-dien-2-one (3g) (Figure 3). The ${ }^{19} \mathrm{~F} \mathrm{NMR}$ data were compatible with already observed chemical shift values for $\alpha, \beta$-unsaturated trifluoromethyl ketones or enolized trifluoromethyl- $\beta$-diketones ranging from -78 to $-76 \mathrm{ppm}$ to trifluoromethyl substituted series $\mathbf{3}$ and $\mathbf{5}{ }^{48}$
Trichloromethyl-substituted derivative $\mathbf{4}$ also showed a set of characteristic signals for the nuclei of the constituent atoms of the enone entity, in addition to the characteristic signals for each substituent coming from the precursor methyl ketones. In these compounds, the ${ }^{1} \mathrm{H}$ NMR spectra showed common characteristics including singlet signals from vinylic H-3 (H-5 for ester 4m, and H-6 for ester 4n) at high-field $\delta 5.9$ to $6.0 \mathrm{ppm}$ and the methoxy group at $\delta$ 3.8-4.0 ppm; both were more deshielded than the respective trifluoromethyl-substituted derivatives, and the other signals were due to the alkyl from the starting ketone. Further support for acylated products was provided by the ${ }^{13} \mathrm{C}$ NMR spectra. Pattern $4 \mathrm{~g}$ showed high-field signals from carbonyl C-2 and enol ether C-4 at $\delta 179.9$ and $183.3 \mathrm{ppm}$, respectively. There was a signal from vinylic $\mathrm{C}-3$ at $\delta 90.2 \mathrm{ppm}$, a short signal from $\mathrm{CCl}_{3}$ at $\delta 98.0 \mathrm{ppm}$, an intense signal from the methoxy group at $\delta 56.2 \mathrm{ppm}$, signals from methylenes at $\delta 35.3$ and $25.7 \mathrm{ppm}$, and signals at $\delta 132.8,122.5,25.6$, and $17.6 \mathrm{ppm}$ from the other carbons in the substituent chain (see Supplementary Information (SI) section).

The ${ }^{1} \mathrm{H}$ NMR spectra for 3-(ethoxymethylene)1,1,1-trihalotridecan-2-one showed characteristic signals of the enone system, including a signal from vinylic hydrogen at $\delta 7.5$ to $8.0 \mathrm{ppm}$, one from the ethoxy group at $\delta 1.39$ $\left(\mathrm{t}, J_{\mathrm{HH}} 6.8 \mathrm{~Hz}\right)$ and $4.2 \mathrm{ppm}\left(\mathrm{q}, J_{\mathrm{HH}} 6.8 \mathrm{~Hz}\right)$, and the pattern signal set of a ten-carbon fatty chain (see SI section). ${ }^{13} \mathrm{C}$ NMR data indicated that the enone $\mathrm{C}-2$ was the more deshielded signal at $\delta 179.7 \mathrm{ppm}$ with ${ }^{2} J_{\mathrm{CF}} 34 \mathrm{~Hz}$; the signal from C-4 at $\delta 164.2$ ppm was a quartet with ${ }^{4} J_{\mathrm{CF}} 5 \mathrm{~Hz}$; and the signals from $\mathrm{CF}_{3}$ and $\mathrm{C}-3$ appeared at $\delta 117.0$ and $117.1 \mathrm{ppm}$, respectively, forming an interesting set, a large quartet with $J_{\mathrm{CF}} 291 \mathrm{~Hz}$ and an intense signal almost in the middle (see SI section). 

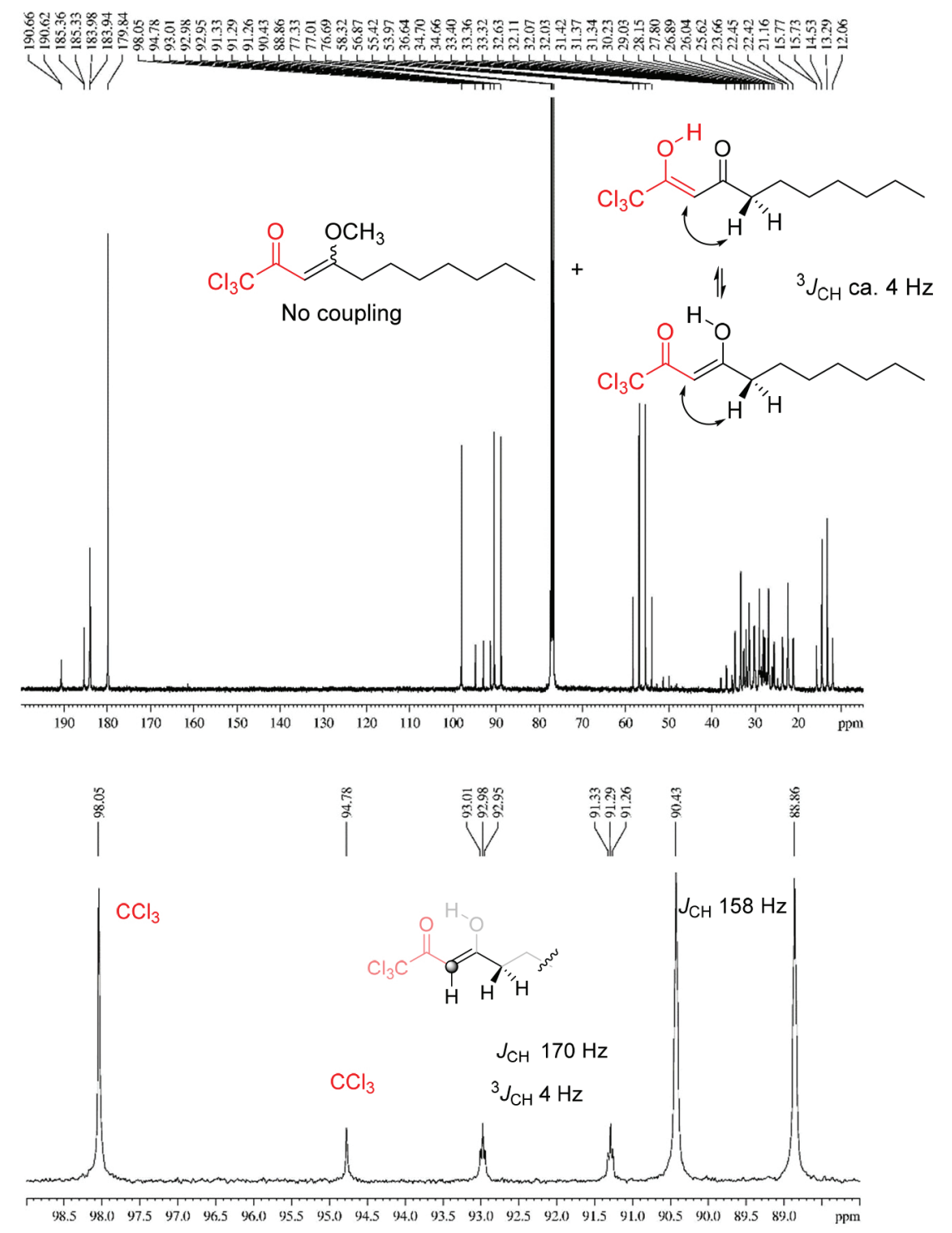

V.
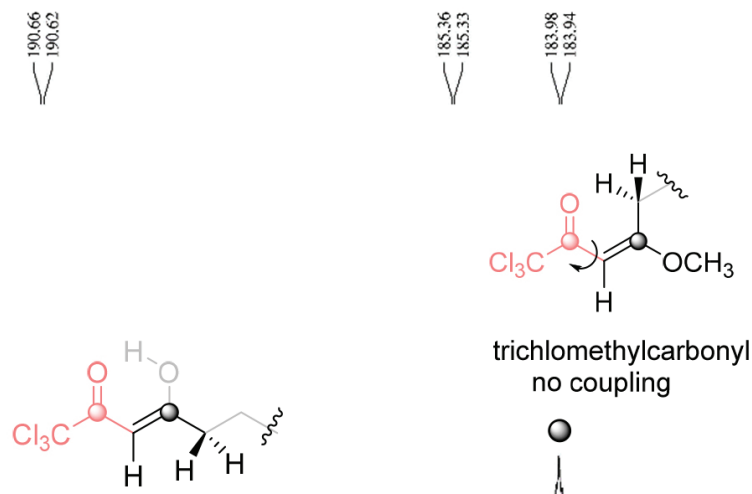

trichlomethylcarbonyl no coupling

trichloromethylcarbonyl doublet ${ }^{2} \mathrm{~J}_{\mathrm{CH}} 3 \mathrm{~Hz}$

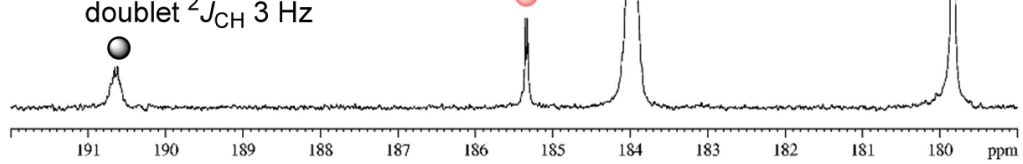

Figure 3. ${ }^{13} \mathrm{C}\{\mathrm{H}\}$ NMR spectra from mixture $4 \mathbf{a}+\mathbf{6 a}$. 
For the series of 6-aryl-1,1,1-trifluorohexan-2,4-diones $\mathbf{5 h}$-j obtained from acid hydrolysis of the 6-aryl1,1,1-trifluoro-4-methoxyhex-3-en-2-ones $\mathbf{3 h} \mathbf{\mathbf { h }}$, in which the substituents were not susceptible to the acid medium used, the spectrum pattern for ${ }^{1} \mathrm{H}$ NMR showed, as the most remarkable characteristic, the disappearance of the signal due to the methoxy group. The H-3 signal was slightly deshielded to $5.9 \mathrm{ppm}$, and the enolic $\mathrm{OH}$ was not clearly observed due to fast exchange with residual water in the $\mathrm{CDCl}_{3}$. The ${ }^{13} \mathrm{C}$ NMR spectra presented very evident differences in chemical shifts, $\mathrm{C}-\mathrm{F}$ coupling constants, and multiplicity of the signals from the enone system carbons. For example, the signal for $\mathrm{C}-2$ in enone $\mathbf{3 h}$ appeared at $\delta 178.9 \mathrm{ppm}$ with ${ }^{3} J_{\mathrm{CF}} 33 \mathrm{~Hz}$, whereas in the diketone 5h the signal for C-2 was shielded by 4 ppm appearing at $\delta 174.8 \mathrm{ppm}$ with ${ }^{2} J_{\mathrm{CF}} 36 \mathrm{~Hz}$. The C-4 in enone $\mathbf{3 h}$ appeared at $\delta 184.4 \mathrm{ppm}$ while the $\mathrm{C}-4$ in the diketone $\mathbf{5 h}$ was deshielded by $12 \mathrm{ppm}$ at $\delta 196.5 \mathrm{ppm}$.

The signals for $\mathrm{CF}_{3}$ carbon appeared at $\delta 117.1 \mathrm{ppm}$ for both enone and diketone, nevertheless the $J_{\mathrm{CF}}$ values differed by $10 \mathrm{~Hz}$, with $292 \mathrm{~Hz}$ for $\mathrm{CF}_{3}$ in enone $\mathbf{3 h}$ and $282 \mathrm{~Hz}$ in diketone $\mathbf{5 h}$. Also important was the chemical shift variance and coupling constant ${ }^{3} J_{\mathrm{CF}}$ of C-3 in the diketone product relative to enone, as it appeared at $91.7 \mathrm{ppm}$ without $\mathrm{CF}$ coupling for $\mathbf{3 h}$ and was deshielded at $\delta 96.2 \mathrm{ppm}$ with ${ }^{3} J_{\mathrm{CF}} 2 \mathrm{~Hz}$ for diketone $\mathbf{5} \mathbf{h}$. The trifluoromethyl- $\beta$-diketones showed a remarkable preference for keto-enol forms in $\mathrm{CDCl}_{3}$, with the intramolecular hydrogen bond.

When $\mathrm{R}=$ alkyl groups, as the series synthesized here, the dynamic equilibrium constant between forms $\mathrm{A}$ and B (Figure 4) is near unity. ${ }^{6}$ However, considering the correlation between $\mathrm{CF}$ coupling constants and alkene configuration described by Bégué et al. ${ }^{45}$ for trifluoromethylated vinyl compounds, we can conclude that the keto-enol form preferred is A, because we observed a ${ }^{3} J_{\mathrm{CF}}$ around $2.0 \mathrm{~Hz}$ for isolated product 5 . The methoxy group in enone $\mathbf{3}$ fixed the resonant push-pull system and caused the adoption of a geometry that does not favor coupling between $\mathrm{C}-3$ and the $\mathrm{F}$ atoms of the trifluoromethyl group.

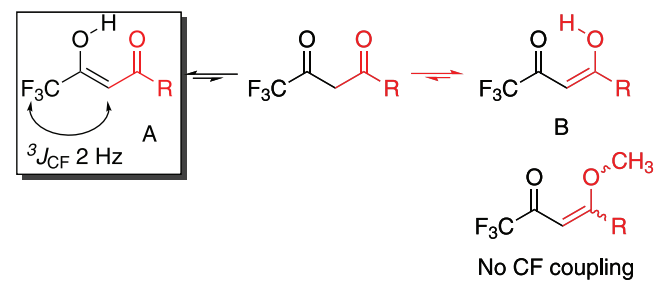

Figure 4. Keto-enol tautomeric forms for diketones $\mathbf{5 h}-\mathbf{k}$.

For trichloromethyl- $\beta$-diketones, the ${ }^{1} \mathrm{H}$ NMR spectrum showed signals from $\mathrm{H}-3$ as a singlet at $6.0 \mathrm{ppm}$ for $\mathbf{6 h}$, together with methylene multiplets at 2.71 and $2.98 \mathrm{ppm}$ and phenyl hydrogens as a broad multiplet at 7.18-7.30 ppm, demonstrating the presence of an enone (keto-enol) form in $\mathrm{CDCl}_{3}$ solution. The ${ }^{1} \mathrm{H} \mathrm{NMR}$ spectrum from $\mathbf{6 k}$ showed that this hydrolyzed product exists in an enone form as well as in a diketo form when in $\mathrm{CDCl}_{3}$ solution. The signal from vinylic $\mathrm{H}-3$ was a singlet at $\delta 6.28 \mathrm{ppm}$, and doublet signals at $\delta 4.28$ and $4.43 \mathrm{ppm}$ were attributed to diastereotopic methylene between the two carbonyls of the diketo form, with a geminal coupling constant of $J_{\mathrm{HH}} 16.4 \mathrm{~Hz}$. Besides the two quartets from $\mathrm{H}-5$ at $\delta 3.39$ and $3.51 \mathrm{ppm}$ with $J_{\mathrm{HH}} 7.0 \mathrm{~Hz}$, at a 3:1 ratio between the enone and keto forms, the spectrum showed two singlet signals from the thiomethyl group and two doublets from the terminal $\mathrm{CH}_{3}$.

Here we also present the ${ }^{13} \mathrm{C}\left\{{ }^{1} \mathrm{H}\right\}$ spectrum of the $4 \mathbf{a}$ / $\mathbf{6 a}$ mixture to demonstrate that, in the trichloroacetylated derivatives $\mathbf{4}$ and $\mathbf{6}$, a different trend was observed for the chemical shifts of the carbon nuclei when comparing enone and diketone trifluoroacetylated derivatives, $\mathbf{3}$ and $\mathbf{5}$, respectively. The signal for $\mathrm{C}-2$ in enone $\mathbf{4 a}$ appeared at $\delta 179.8 \mathrm{ppm}$ without hydrogen coupling, whereas in the diketone $\mathbf{6 a}$ the signal for $\mathrm{C}-2$ was deshielded by $5 \mathrm{ppm}$ appearing at $\delta 185.3 \mathrm{ppm}$ with ${ }^{2} J_{\mathrm{CH}} 3 \mathrm{~Hz}$. The $\mathrm{C}-4$ in enone 4a appeared at $\delta 183.9 \mathrm{ppm}$ while the $\mathrm{C}-4$ in the diketone 6a was deshielded by $6 \mathrm{ppm}$ at $\delta 190.6 \mathrm{ppm}$. The signals for $\mathrm{CCl}_{3}$ carbon appeared at $\delta 98$ and $94.8 \mathrm{ppm}$ for enone and diketone, respectively. C-3 signals included a doublet at $89.6 \mathrm{ppm}$ with $J_{\mathrm{CH}} 158 \mathrm{~Hz}$ for enone $\mathbf{4 a}$ and a doublet of triplets at $92.1 \mathrm{ppm}$ with $J_{\mathrm{CH}} 170 \mathrm{~Hz}$ and ${ }^{3} J_{\mathrm{CH}} 3 \mathrm{~Hz}$ in diketone 6a (Figure 3).

[3 + 2] Cyclocondensation of 1,1,1-trihalo-4-methoxyalk3 -en-2-ones and their respective trihalomethyl- $\beta$-diketones and hydroxilamine

The experimental procedure for these cyclocondensation reactions is very simple and allows the use of green solvents to an extent. Our experiments showed that the reaction between hydroxylamine hydrochloride and 1,1,1-trihalomethyl-4-alkoxy-3-alken-2-ones 3 or $\mathbf{4}$, leading to 5-hydroxy-5-trihalomethyl-4,5-dihydroisoxazoles 8 or $\mathbf{9}$, can be catalyzed by bases or acids. The reaction medium $\mathrm{pH}$ is around 7-8 starting from a mixture with equimolar amounts of $\mathrm{NaOH}$ and hydroxylamine hydrochloride and dielectrophile precursor ( $\mathbf{8}$ or $\mathbf{9})$ in water, methanol, or ethanol, reacting under neutral conditions. The mixture $\mathrm{pH}$ is around 1-2 in water, methanol, or ethanol, when starting from a mixture of only hydroxylamine hydrochloride and dielectrophile precursor, without adding other promoters. All of these reaction media led to 
the same products, namely, 5-hydroxy-5-trihalomethyl4,5-dihydroisoxazole 8 or $\mathbf{9}$, and at very similar yields. Similar results were obtained when the dielectrophilic precursor in cyclocondensation with hydroxylamine was a trihalomethyl- $\beta$-diketone $\mathbf{5}$ or $\mathbf{6}$. Caution must be taken not to add $\mathrm{NaOH}$ to the trichloromethyl- $\beta$-diketone, which causes the haloform reaction. ${ }^{49}$

The cyclization of trifluoromethyl-1,3-dielectrophiles 3h-l or trichloromethyl-1,3-dielectrophilic precursors 4a-h, 4k-n with hydroxylamine hydrochloride proceeded smoothly in $\mathrm{EtOH}$ at $50{ }^{\circ} \mathrm{C}$ for $4-8 \mathrm{~h}$. Because ethanol functions with the entire set of trihalomethyl-1,3-dielectrophiles studied in this work, it was chosen as the solvent, although cyclization of 1,1,1-trichloromethyl-4-methoxy-3-alken-2-ones to the isoxazoles has already been done in water. ${ }^{50}$ After completion of the reaction, the solvent was evaporated, and solid residues were purified by recrystallization from hexane. White solids with a fibrous texture were obtained in isolated yields of $85-90 \%$ and attributed as 5-hydroxy5-trifluoromethyl-4,5-dihydroisoxazoles $\mathbf{8 g}, \mathbf{h}, \mathbf{k}-\mathbf{m}$ or 5-hydroxy-5-trichloromethyl-4,5-dihydroisoxazoles 9a-c,f-h,k,m (Scheme 7), which were fully characterized by NMR spectroscopy and electrospray ionization (ESI) high-resolution mass spectrometry (HRMS).

The ${ }^{1} \mathrm{H}$ NMR spectrum of 5-hydroxy-5-trifluoromethyl4,5-dihydroisoxazole $\mathbf{8 1}$ exhibited only one set of signals: the characteristic two doublets at $\delta 3.0$ and $3.22 \mathrm{ppm}$ with germinal ${ }^{2} J_{\mathrm{HH}} 18.4 \mathrm{~Hz}$ for the diastereotopic hydrogens at the 4-position of the isoxazole ring. In addition, there were signals from the hydrogens of the methoxy group as a singlet at $\delta 3.86 \mathrm{ppm}$, from the methylene in the benzyl entity as a singlet at $\delta 3.77 \mathrm{ppm}$, and from aromatic ring between 6.91 and $7.32 \mathrm{ppm}$ (see SI section). However, the 4,5-dihydroisoxazoles $8 \mathbf{k}, 9 \mathbf{k}$ were a mixture of disteroisomers, because we started from 3-thiomethyl-2-butanone as a racemate. For example, the ${ }^{1} \mathrm{H}$ NMR spectrum for $9 \mathbf{k}$ displayed two sets of signals for diastereotopic H-4 with large variation in chemical shifts, four doublets at $\delta 3.37,3.99,3.78$ and $3.88 \mathrm{ppm}$. These data prove that, during the process of cyclocondensation, there is an intermediate that allows the closure of the hemicetal entity in the C- 5 by $R e$ or $\mathrm{Si}$ faces (Figure 5).

The ${ }^{1} \mathrm{H}$ NMR spectrum of $\mathbf{9 g}$ displayed dihydroisoxazole $\mathrm{H}-4$ diasterotopic hydrogens as an $\mathrm{AB}$ system, with doublets at $\delta 3.2$ and $3.63 \mathrm{ppm}$ and a geminal coupling constant at ${ }^{2} J 18.8 \mathrm{~Hz}$. The $\mathrm{H}-4$ that is cis to $\mathrm{CCl}_{3}$ was attributed to the downfield doublet $\delta 3.63 \mathrm{ppm}$, whereas 4-H, which is cis to the hydroxyl group, was attributed to the upfield doublet $\delta 3.20 \mathrm{ppm}$. For the 2a-f series, the other ${ }^{1} \mathrm{H}$ NMR signals were characteristic of the saturated fatty chain at 3-position of the isoxazole ring, with a triplet from $\alpha$-methylene at $\delta 2.41 \mathrm{ppm}$, a quintet from $\beta$-methylene at $\delta 1.60 \mathrm{ppm}$, a broad signal from internal methylenes at $\delta 1.35 \mathrm{ppm}$, and a triplet from the terminal methyl at $\delta 0.80 \mathrm{ppm}$. The ${ }^{13} \mathrm{C}$ NMR spectra of 5-hydroxy5-trichloromethyl-4,5-dihydroisoxazoles displayed C-3, C-4, and C-5 signals at approximately $\delta 160,46$, and $110.4 \mathrm{ppm}$, respectively. The $\mathrm{CCl}_{3}$ carbon displayed a characteristic small signal at approximately $\delta 101 \mathrm{ppm}$, and the saturated fatty substituent gave rise to a set of signals at a high field, between $\delta 14$ and $32 \mathrm{ppm}$.

The details of the spectroscopic data for 5-hydroxy-3-(4-methyl-3-pentenyl)-5-trichloromethyl4,5-dihydroisoxazol $(\mathbf{9 g})$ are shown in the Experimental section.

The compounds 9a-c,e,f were dehydrated in $98 \%$ $\mathrm{H}_{2} \mathrm{SO}_{4}$ to produce trichloromethyl-substituted isoxazoles 11a-c,e,f (Scheme 7). Aromatization occurred smoothly at $25{ }^{\circ} \mathrm{C}$, and white needle compounds (9) readily dissolved in concentrated sulfuric acid, forming slightly yellowish solutions. These were maintained under stirring for a further $2 \mathrm{~h}$. Then the reaction was treated with ice water and extracted twice with ethyl acetate. The solvent was evaporated to obtain yellowish oil residues at excellent yields (>90\%); these were assigned as 5-trichloromethylisoxazole 11. The compound was also characterized by its ${ }^{1} \mathrm{H} /{ }^{13} \mathrm{C}$ NMR spectra, which displayed a characteristic singlet signal at around $\delta 6.47 \mathrm{ppm}$; furthermore, the signals for isoxazole carbons C-3, C-4,

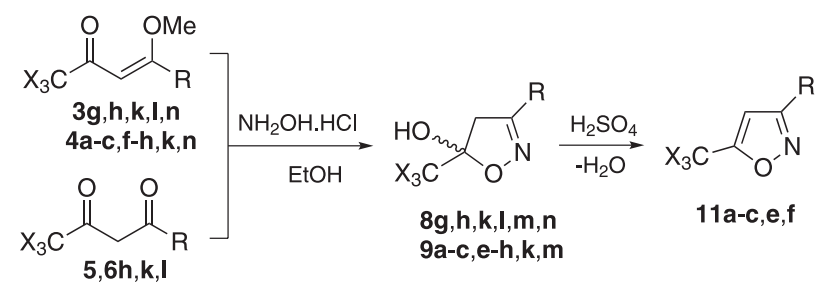

$\mathrm{R}=n$-heptyl (a), n-octyl (b), n-nonyl (c), n-undecyl (e), n-tridecyl (f), $\mathrm{CH}_{2} \mathrm{CH}_{2} \mathrm{CH}=\mathrm{C}\left(\mathrm{CH}_{3}\right)_{2}$ (g),

$\mathrm{CH}_{2} \mathrm{CH}_{2} \mathrm{Ph}(\mathbf{h}), \mathrm{CH}\left(\mathrm{SCH}_{3}\right) \mathrm{CH}_{3}(\mathbf{k}), \mathrm{CH}_{2}\left(\mathrm{CH}_{3} \mathrm{OC}_{6} \mathrm{H}_{4}\right)(\mathrm{I}), \mathrm{CH}_{2} \mathrm{CH}_{2} \mathrm{CO}_{2} \mathrm{CH}_{3}$ (m)

Scheme 7. Cyclocondensation to trihalomethylisoxazole derivatives. 


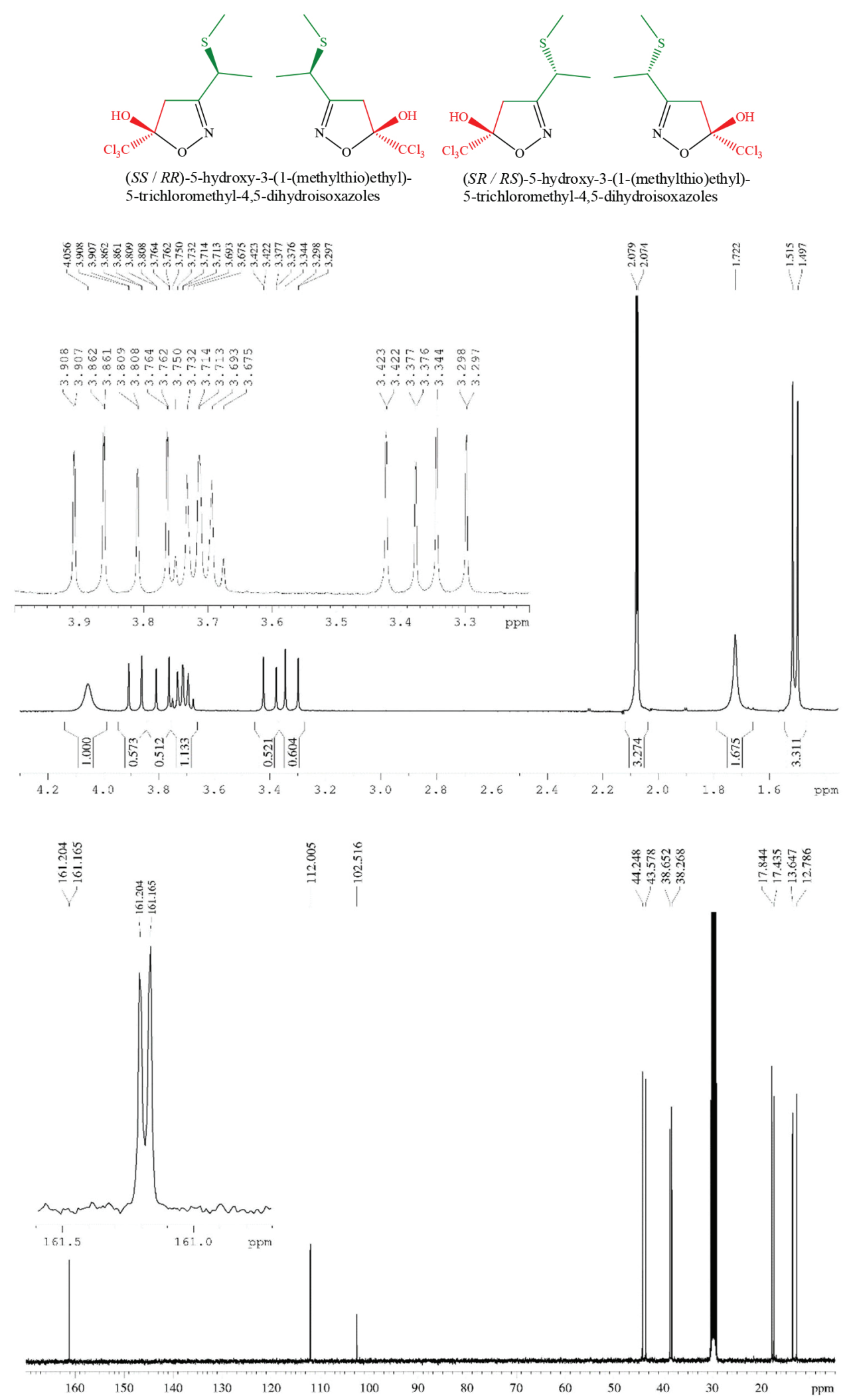

Figure 5. ${ }^{1} \mathrm{H}$ and ${ }^{13} \mathrm{C}$ (acetone- $d_{6}$ ) NMR spectra of two diatereoisomeric pair mixtures of isoxazole $9 \mathbf{k}$.

and C-5 in compound $\mathbf{1 1}$ appeared at $\delta 164,103$, and $168 \mathrm{ppm}$, respectively.
The dehydration reaction of 5-trichloromethyl4,5-dihydroisoxazoles in acidic media is a second-order 
elimination reaction [E2 (E1-like)], in which the stability of the activated complex depends on the participation of the electron pair of the neighboring oxygen atom (O-1) in the isoxazole ring and on the electron-donating effects of the group attached to the $\mathrm{C}-5$ of the isoxazole ring. ${ }^{51}$ Attempts to conduct the reaction until complete conversion of the trichloromethyl group into the carboxyl acid-ester were unsuccessful. For example, a reaction between $\mathbf{4 c}$ and $\mathrm{NH}_{2} \mathrm{OH} . \mathrm{HCl}$ in EtOH and a 30\% sulfuric acid solution under reflux for 8 to $20 \mathrm{~h}$ produced a mixture of products consisting of a 53\% majority of 5-trichloromethyl-5-hydroxy4,5-dihydroisoxazole (9c), 20\% 5-trichloromethylisoxazole (11c), 21\% 3-trichloromethylisoxazole (12c), and 6\% isoxazole-5-carboxylic acid (13c) (Scheme 8, Figure 6).

[3+2] Cyclocondensation of 1,1,1-trihalo-4-methoxyalk-3en-2-ones and their respective trihalomethyl- $\beta$-diketones with hydrazine and hydrazides

The experimental procedure for $1 H$-pyrazole derivative cyclocondensation is also simple, allowing the use of ecofriendly ethanol. The reaction between hydrazine hydrochloride and 1,1,1-trifluoromethyl-4-alkoxy3-alken-2-ones $\mathbf{3 h}, \mathbf{j}$, leading to 5(3)-trifluoromethyl$1 H$-pyrazoles $\mathbf{1 2 h}, \mathbf{j}$, occurred smoothly and efficiently. The reaction medium $\mathrm{pH}$ was around 3.0 to 3.5 starting from a mixture with equimolar amounts of hydrazine hydrochloride and dielectrophile precursors $\mathbf{3 h}, \mathbf{j}$ in ethanol, reacting in a slightly acidic medium. The mixture $\mathrm{pH}$ was around 5-6 in ethanol, when starting from $\beta$-diketone dielectrophile precursor $\mathbf{5 h}, \mathbf{j}$ without adding other promoters. Both precursors $\mathbf{3}$ and $\mathbf{5}$ led to the same product, 5(3)-trifluoromethyl- $1 H$-pyrazoles $\mathbf{1 2} \mathbf{h}, \mathbf{j}$, in very similar quantitative yields.
$[\mathrm{CCC}+\mathrm{NN}]$ cyclocondensation of alkenones 3-6 and hydrazine for $1 H$-pyrazole derivatives was also simple, allowing the use of ecofriendly ethanol. The reaction between hydrazine hydrochloride and 1,1,1-trifluoromethyl4-alkoxy-3-alken-2-ones $\mathbf{3 h}, \mathbf{j}$, leading to tautomeric 5(3)-trifluoromethyl- $1 H$-pyrazoles $\mathbf{1 2 h}, \mathbf{j}$, occurred smoothly and efficiently. The reaction medium $\mathrm{pH}$ was around 3.5 to 4.0 starting from a mixture with equimolar amounts of hydrazine hydrochloride and precursors $\mathbf{3 h}, \mathbf{j}$ in ethanol, reacting in a slightly acidic medium. The mixture $\mathrm{pH}$ was around 5-6 in ethanol, when starting from $\beta$-diketone precursor $\mathbf{5 h}, \mathbf{j}$ without adding other promoters (Scheme 9). Both precursors $\mathbf{3}$ and $\mathbf{5}$ led to the same product, 5(3)-trifluoromethyl- $1 H$-pyrazoles $\mathbf{1 2 h}, \mathbf{j}$, in very similar quantitative yields. The $1 H$-pyrazoles were identified by ${ }^{1} \mathrm{H},{ }^{13} \mathrm{C}$ and ${ }^{19} \mathrm{~F}$ NMR spectroscopy and by MS. The ${ }^{1} \mathrm{H}$ NMR spectrum of the 5(3)-trifluoromethyl3(5)-(2-phenylethyl)-1 $H$-pyrazole (12h) displayed an aromatic $\mathrm{H} 4$ at $\delta 6.3 \mathrm{ppm}$, signals from the ethylene spacer as a coalescent multiplet at $\delta 2.99 \mathrm{ppm}$, and signals from aromatic hydrogens as multiplets at $\delta 7.17$ and $7.29 \mathrm{ppm}$. The ${ }^{13} \mathrm{C}$ NMR data also conformed to the structure of $\mathbf{1 2 h}$, with signals from pyrazole cycle $\mathrm{C} 3$ at $\delta 144.7 \mathrm{ppm}, \mathrm{C} 5$ at $\delta 143.0 \mathrm{ppm}$ with ${ }^{2} J_{\mathrm{CF}} 38 \mathrm{~Hz}$, and $\mathrm{C} 4$ at $102.2 \mathrm{ppm}$ with ${ }^{3} J_{\mathrm{CF}} 1.5 \mathrm{~Hz}$, along with signals from a phenyl ring at $\delta 139.9$, $128.7,128.3$, and $126.6 \mathrm{ppm}$, a remarkable quartet from $\mathrm{CF}_{3}$ at $121.3 \mathrm{ppm}$ with $J_{\mathrm{CF}} 268 \mathrm{~Hz}$, and signals from an ethylene spacer at $\delta 35.0$ and $27.1 \mathrm{ppm}$. Finally, the ${ }^{19} \mathrm{~F}$ NMR spectra showed a singlet signal at $\delta-62$ to $-62.1 \mathrm{ppm}$, which is typical for trifluoromethyl group in the predominant tautomer 3-trifluoromethyl-5-phenylethyl-1 $H$-pyrazole. ${ }^{52}$

The reaction between $4 \mathbf{h}$ or $\mathbf{6} \mathbf{h}$ and $\mathrm{NH}_{2} \mathrm{NH}_{2} \cdot \mathrm{HCl}$ in alcohol solvent, ethanol, or 2-methoxyethanol, was conducted at the reflux temperature of the solvent for

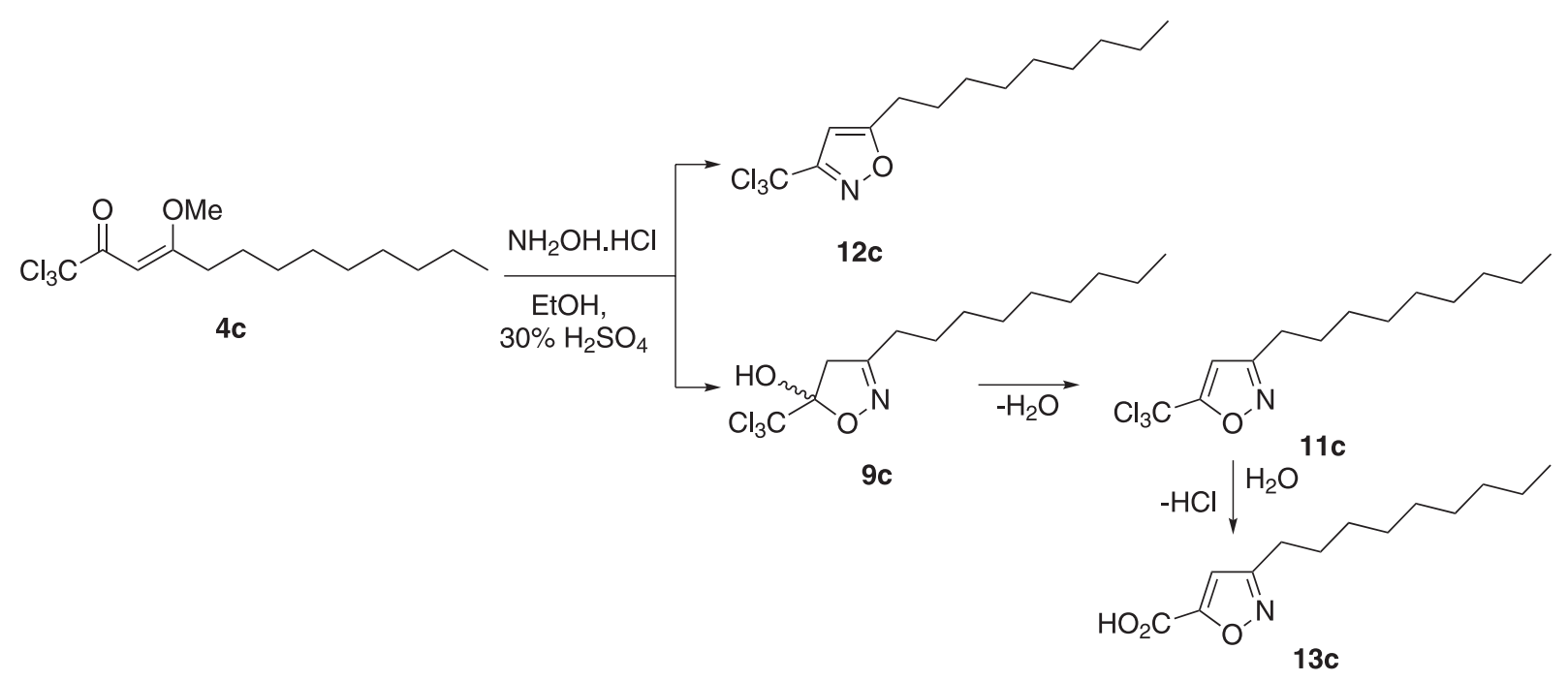

Scheme 8. Cyclocondensation with $\mathrm{NH}_{2} \mathrm{OH}$ in EtOH / $\mathrm{H}_{2} \mathrm{SO}_{4}$ solution. 

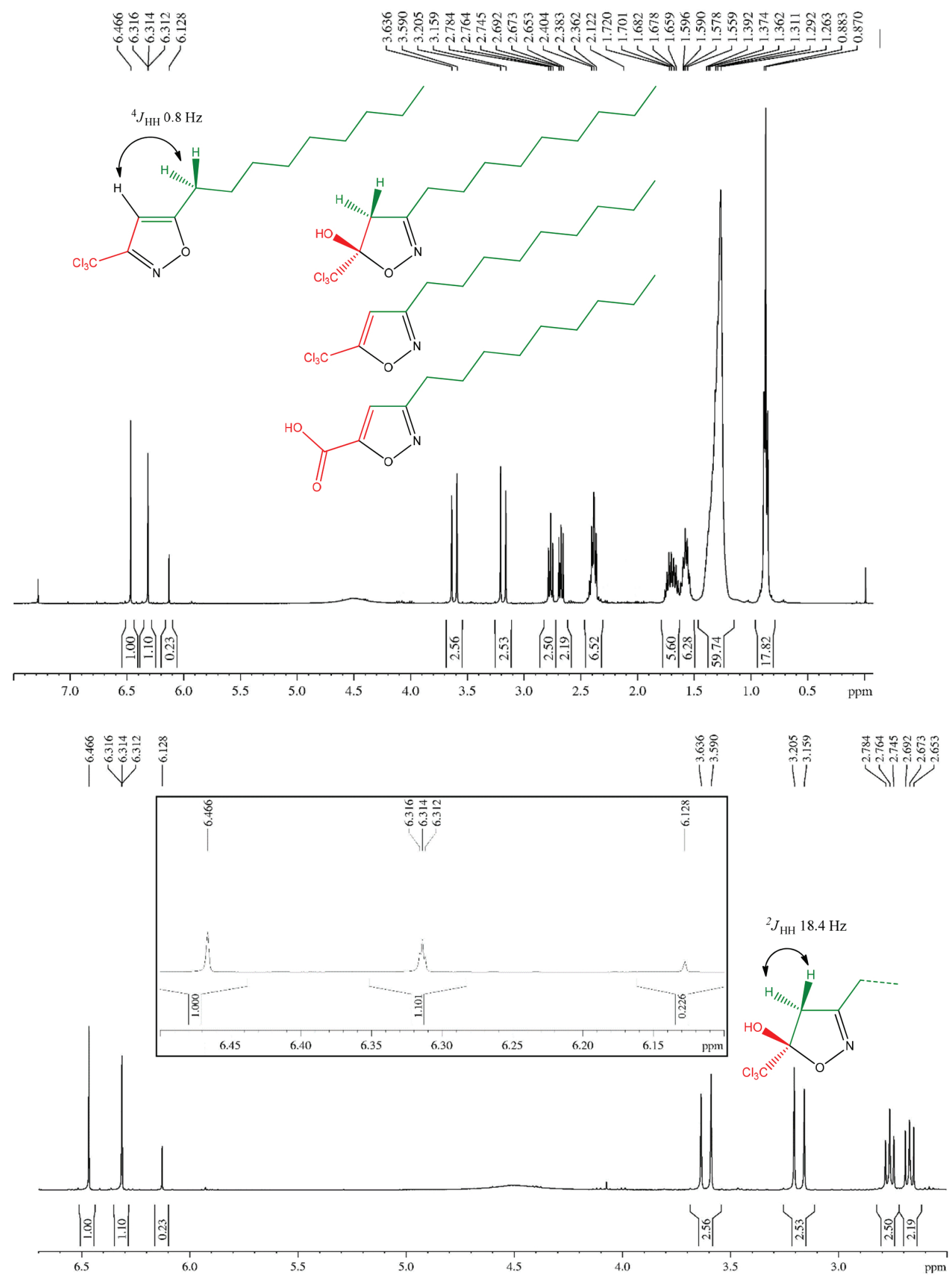

Figure 6. ${ }^{1} \mathrm{H}$ NMR spectrum of a mixture obtained from a reaction between $4 \mathbf{c}$ and $\mathrm{NH}_{2} \mathrm{OH} . \mathrm{HCl}$ in $30 \% \mathrm{H}_{2} \mathrm{SO}_{4}$.

5-10 h. Then the solvent was distilled off and the solid residue was characterized by NMR as alkyl 3-phenethyl$1 H$-pyrazole 5-carboxylate (Scheme 9). The $[3+2]$ cyclocondensation performed in an alcohol solvent according to a previously described method led to the intermediate aromatic 5(3)-trichloromethyl- $1 H$-pyrazole; thereafter, the trichloromethyl group was hydrolyzed, leading to $1 H$-pyrazole-5(3)-carboxylates..$^{38,41}$ 


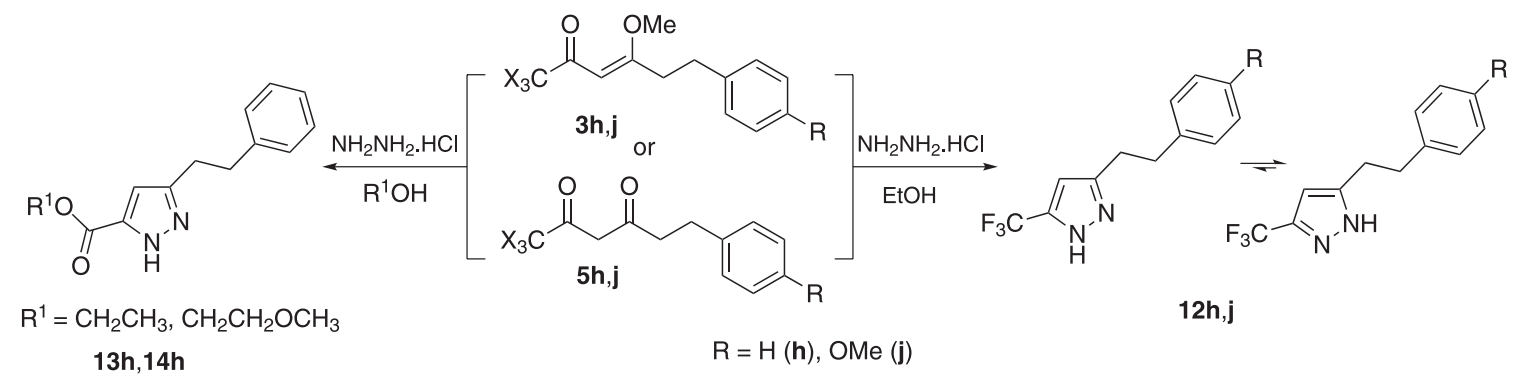

Scheme 9. Cyclocondensation to trifluoromethyl-1H-pyrazole derivatives.

The $1 H$-pyrazole-5(3)-carboxylates were identified by ${ }^{1} \mathrm{H}$ and ${ }^{13} \mathrm{C}$ NMR spectroscopy and by MS. The ${ }^{1} \mathrm{H}$ NMR spectrum of the 3(5)-(2-phenylethyl)- $1 H$-pyrazole5(3)-carboxylates $(\mathbf{1 5}, \mathbf{1 6 h})$ displayed an aromatic $\mathrm{H} 4$ at $\delta 6.6 \mathrm{ppm}$, signals from the ethylene spacer between pyrazole and phenyl rings as multiplets at $\delta 2.95$ and $3.15 \mathrm{ppm}$, and signals from aromatic hydrogens as multiplets at $\delta 7.12$ and $7.25 \mathrm{ppm}$, in addition to the characteristic signals of the alkyl substituent from alcohol. The ${ }^{13} \mathrm{C}$ NMR data also confirmed the structure of 3(5)-(2-phenylethyl)- $1 H$-pyrazole5(3)-carboxylates $(\mathbf{1 5}, \mathbf{1 6 h})$; signals from the pyrazole cycle at $\delta 149,138$, and 107-108 ppm; from a phenyl ring at $\delta 139-140,128$, and $126 \mathrm{ppm}$; from carboxyl ester at $\delta$ $156-157 \mathrm{ppm}$; and from the ethylene spacer at $\delta 34-35$ and 27-28 ppm.

\section{Conclusions}

We demonstrate the wide scope of the acetal acylation method for production of 1,3-dielectrophiles with diverse functionalized substituents, including prenyl. This method allows the formation of $\mathrm{C}-\mathrm{C}$ bonds through acylation in a mild acidic medium, allowing precursors with groups that are vulnerable to attack by bases. The 1,3-dielectrophilic products (4-alkoxy-1,1,1-trihaloalk-3-en-2-ones or 1,1,1-trihaloalkan-2,4-diones) are important precursors in the preparation of 1,2-azole heterocycles, and herein we report isoxazoles and $1 H$-pyrazoles with prenyl, phenethyl, and substituted phenethyl entities, and a series with neutral amphiphilic molecular structures.

\section{Experimental}

Unless indicated otherwise, all common reagents were used as obtained from commercial suppliers without further purification. Yields listed are of isolated compounds. ${ }^{1} \mathrm{H}$, ${ }^{13} \mathrm{C}$, and ${ }^{19} \mathrm{~F}$ NMR spectra were acquired on a Bruker DPX 200, Bruker DPX 400, or Ascend 400 spectrometer at $300 \mathrm{~K}$, using $5 \mathrm{~mm}$ sample tubes, and with a digital resolution of $\pm 0.01 \mathrm{ppm}$. $\mathrm{CDCl}_{3}$ was used as a solvent with tetramethylsilane (TMS) as the internal standard. Chemical shifts are expressed in ppm and coupling constants in $\mathrm{Hz}$. The following NMR abbreviations were used: $\mathrm{s}=$ singlet, $\mathrm{d}=$ doublet, $\mathrm{t}=$ triplet, $\mathrm{q}=$ quartet, $\mathrm{m}=$ multiplet, $\mathrm{dd}=$ doublet of doublet. Melting points were determined using open capillaries on a Fisatom 431 apparatus and are uncorrected. HRMS analyses: the compounds were dissolved in acetonitrile (Merck, West Point, USA) and deionized water $(50 \%$ (v/v) with $0.1 \%$ formic acid. The dissolved compounds were injected individually into the ESI source using a syringe pump (Harvard Apparatus) at a flow rate of $150 \mu \mathrm{L} \mathrm{min}^{-1}$. ESI(+)-MS and tandem ESI(+)-MS/MS data were acquired using a hybrid high-resolution and high-accuracy $\left(5 \mu \mathrm{L} \mathrm{L}^{-1}\right)$ microTof (quadrupole time of flight (QTOF)) MS (Bruker Scientific). Conditions: cone voltages were set to +3500 and $+40 \mathrm{~V}$, respectively, with a de-solvation temperature of $100{ }^{\circ} \mathrm{C}$. For ESI (+)-MS/MS, the energy (between 5 and $40 \mathrm{eV}$ ) for collision-induced dissociation (CID) was optimized for each component. Diagnostic ions were identified by comparing the measurements to theoretical ESI(+)-MS/MS data. EI-MS were registered in an HP 5973 MSD connected to an HP 6890 GC and interfaced with a Pentium PC. The GC was equipped with a split-splitless injector and an auto-sampler cross-linked HP-5 capillary column ( $30 \mathrm{~m}, 0.32 \mathrm{~mm}$ internal diameter), and helium was used as the carrier gas.

\section{Acetal acylation methodology}

\section{1,1,1-Trihalo-4-methoxy-3-alken-2-ones}

To a stirred solution of dimethoxy acetal derived from precursor ketones 1a-n $(30 \mathrm{mmol})$ and pyridine $(60 \mathrm{mmol}, 4.8 \mathrm{~g})$ in $\mathrm{CHCl}_{3}(30 \mathrm{~mL})$ kept at $0{ }^{\circ} \mathrm{C}$, a solution of trichloroacetyl chloride $(60 \mathrm{mmol}, 6.8 \mathrm{~mL})$ in $\mathrm{CHCl}_{3}$ $\left(20 \mathrm{~mL}\right.$ ) was added dropwise at $-5{ }^{\circ} \mathrm{C}$. The mixture was stirred for 8-12 $\mathrm{h}$ at room temperature $\left(25-30^{\circ} \mathrm{C}\right)$. After the mixture was quenched with a $2 \mathrm{M} \mathrm{HCl}$ solution $(30 \mathrm{~mL})$, the organic layer was separated and dried with $\mathrm{Na}_{2} \mathrm{SO}_{4}$, the solvent was evaporated, and the residue was distilled to remove methyl trichloroacetate. The products $\mathbf{2 a - g}$ were obtained as black oil with high purity. 
1,1,1-Trifluoro-4-methoxyundec-3-en-2-one (3a)

Yield $88 \%$, reddish oil; IR (film) $v_{\max } / \mathrm{cm}^{-1} 3089$, 2926, 2908, 1592, 1568, 1493, 1455, 1255, 1081; ${ }^{1} \mathrm{H}$ NMR $\left(400 \mathrm{MHz}, \mathrm{CDCl}_{3}\right) \delta 5.6(1 \mathrm{H}, \mathrm{s}, \mathrm{H} 3), 3.78(3 \mathrm{H}, \mathrm{s}, \mathrm{OMe})$, $2.79(2 \mathrm{H}, \mathrm{t}, J 7.8), 1.56(2 \mathrm{H}, \mathrm{m}, J 7.7), 1.32-1.27(8 \mathrm{H}, \mathrm{br}$ $\left.\mathrm{m},\left(\mathrm{CH}_{2}\right)_{4}\right), 0.88\left(3 \mathrm{H}, \mathrm{t}, J 6.7, \mathrm{CH}_{3}\right) ;{ }^{13} \mathrm{C} \mathrm{NMR}(100 \mathrm{MHz}$, $\left.\mathrm{CDCl}_{3}\right) \delta 185.5(\mathrm{C} 4), 178.4\left(\mathrm{C} 2, \mathrm{q}, J_{\mathrm{CF}} 34\right), 116.7(\mathrm{C} 1, \mathrm{q}$, $\left.J_{\mathrm{CF}} 292\right), 91.0$ (C3), $56.4(\mathrm{OMe}), 33.9,31.6,29.3,28.9$, 26.8, $22.5\left(\mathrm{CH}_{2}\right), 13.9\left(\mathrm{CH}_{3}\right)$; HRMS (ESI) $\mathrm{m} / z$, calcd. for $\mathrm{C}_{12} \mathrm{H}_{20} \mathrm{~F}_{3} \mathrm{O}_{2}[\mathrm{M}+\mathrm{H}]^{+}:$253.1415, found: 253.1437; anal. calcd. for $\mathrm{C}_{12} \mathrm{H}_{19} \mathrm{~F}_{3} \mathrm{O}_{2}$ : C 57.13, H 7.59, found: C 57.21, H 7.65.

\section{1,1,1-Trifluoro-4-methoxydodec-3-en-2-one (3b)}

Yield 90\%, reddish oil; IR (film) $v_{\max } / \mathrm{cm}^{-1} 3090$, 2930, 2895, 1595, 1568, 1495, 1455, 1255, 1081; ${ }^{1} \mathrm{H}$ NMR $\left(400 \mathrm{MHz}, \mathrm{CDCl}_{3}\right) \delta 5.63(1 \mathrm{H}, \mathrm{s}, \mathrm{H} 3), 3.80(3 \mathrm{H}, \mathrm{s}, \mathrm{OMe})$, $2.80(2 \mathrm{H}, \mathrm{t}, J 7.8), 1.58(2 \mathrm{H}, \mathrm{m}, J 7.7), 1.37-1.27(10 \mathrm{H}, \mathrm{br}$ $\left.\mathrm{m},\left(\mathrm{CH}_{2}\right)_{5}\right), 0.89\left(3 \mathrm{H}, \mathrm{t}, J 6.7, \mathrm{CH}_{3}\right) ;{ }^{13} \mathrm{C}$ NMR $(100 \mathrm{MHz}$, $\left.\mathrm{CDCl}_{3}\right) \delta 185.5(\mathrm{C} 4), 178.4\left(\mathrm{C} 2, \mathrm{q}, J_{\mathrm{CF}} 33\right), 116.7(\mathrm{C} 1, \mathrm{q}$, $J_{\mathrm{CF}} 292$ ), 91.0 (C3), 56.4 (OMe), 33.8, 31.7, 29.3, 29.2, 29.1, 26.8, $22.6\left(\mathrm{CH}_{2}\right), 13.9\left(\mathrm{CH}_{3}\right)$; HRMS (ESI) $\mathrm{m} / z$, calcd. for $\mathrm{C}_{13} \mathrm{H}_{22} \mathrm{~F}_{3} \mathrm{O}_{2}[\mathrm{M}+\mathrm{H}]^{+}:$267.1572, found: 267.1607; anal. calcd. for $\mathrm{C}_{13} \mathrm{H}_{21} \mathrm{~F}_{3} \mathrm{O}_{2}$ : C 58.63, H 7.95, found: C 58.55, H 8.05.

\section{1,1,1-Trifluoro-4-methoxytridec-3-en-2-one (3c)}

Yield 89\%, reddish oil; IR (film) $v_{\max } / \mathrm{cm}^{-1} 3089$, 2932, 2889, 1592, 1571, 1493, 1457, 1258, 1086; ${ }^{1} \mathrm{H}$ NMR $\left(400 \mathrm{MHz}, \mathrm{CDCl}_{3}\right) \delta 5.63(1 \mathrm{H}, \mathrm{s}, \mathrm{H} 3), 3.78(3 \mathrm{H}, \mathrm{s}, \mathrm{OMe})$, $2.80(2 \mathrm{H}, \mathrm{t}, J 7.7), 1.56(2 \mathrm{H}, \mathrm{m}, J 7.7), 1.37-1.27(12 \mathrm{H}, \mathrm{br}$ $\left.\mathrm{m},\left(\mathrm{CH}_{2}\right)_{6}\right), 0.88\left(3 \mathrm{H}, \mathrm{t}, J 6.7, \mathrm{CH}_{3}\right) ;{ }^{13} \mathrm{C} \mathrm{NMR}(100 \mathrm{MHz}$, $\left.\mathrm{CDCl}_{3}\right) \delta 185.7(\mathrm{C} 4), 178.4\left(\mathrm{C} 2, \mathrm{q}, J_{\mathrm{CF}} 33\right), 116.8(\mathrm{C} 1, \mathrm{q}$, $\left.J_{\mathrm{CF}} 292\right), 91.0(\mathrm{C} 3), 56.7$ (OMe), 33.8, 31.8, 29.4, 29.3, 29.2, 28.9, 26.9, $22.6\left(\mathrm{CH}_{2}\right), 13.9\left(\mathrm{CH}_{3}\right)$; HRMS (ESI) $m / z$, calcd. for $\mathrm{C}_{14} \mathrm{H}_{24} \mathrm{~F}_{3} \mathrm{O}_{2}[\mathrm{M}+\mathrm{H}]^{+}: 281.1728$, found: 281.1762; anal. calcd. for $\mathrm{C}_{14} \mathrm{H}_{23} \mathrm{~F}_{3} \mathrm{O}_{2}$ : C 59.98, H 8.27, found: C 60.07, H 8.38.

\section{1,1,1-Trifluoro-4-methoxytetradec-3-en-2-one (3d)}

Yield 90\%, reddish oil; IR (film) $v_{\max } / \mathrm{cm}^{-1} 3095$, 2932, 2881, 1591, 1570, 1493, 1465, 1258, 1085; ${ }^{1} \mathrm{H}$ NMR $\left(400 \mathrm{MHz}, \mathrm{CDCl}_{3}\right) \delta 5.64(1 \mathrm{H}, \mathrm{s}, \mathrm{H} 3), 3.78(3 \mathrm{H}, \mathrm{s}, \mathrm{OMe})$, 2.79 ( $2 \mathrm{H}, \mathrm{t}, J 7.8), 1.56$ ( $2 \mathrm{H}, \mathrm{m}, J$ 7.6), $1.36-1.27$ (16H, br $\left.\mathrm{m},\left(\mathrm{CH}_{2}\right)_{8}\right), 0.88\left(3 \mathrm{H}, \mathrm{t}, J 7.0, \mathrm{CH}_{3}\right) ;{ }^{13} \mathrm{C}$ NMR $(100 \mathrm{MHz}$, $\left.\mathrm{CDCl}_{3}\right) \delta 185.4(\mathrm{C} 4), 178.4\left(\mathrm{C} 2, \mathrm{q}, J_{\mathrm{CF}} 33\right), 116.8(\mathrm{C} 1, \mathrm{q}$, $\left.J_{\mathrm{CF}} 292\right), 91.0(\mathrm{C} 3), 56.5(\mathrm{OMe}), 33.8,31.9,29.5,29.4$, 29.3, 29.2, 28.9, 26.9, $22.6\left(\mathrm{CH}_{2}\right), 13.9\left(\mathrm{CH}_{3}\right)$; HRMS (ESI) $m / z$, calcd. for $\mathrm{C}_{15} \mathrm{H}_{26} \mathrm{~F}_{3} \mathrm{O}_{2}[\mathrm{M}+\mathrm{H}]^{+}: 295.1885$, found: 295.1914; anal. calcd. for $\mathrm{C}_{15} \mathrm{H}_{25} \mathrm{~F}_{3} \mathrm{O}_{2}$ : C 61.21, H, 8.56, found: C 61.27, H 8.66.

\section{1,1,1-Trifluoro-4-methoxypentadec-3-en-2-one (3e)}

Yield 91\%, reddish oil; IR (film) $v_{\max } / \mathrm{cm}^{-1} 3094$, 2931, 2885, 1590, 1575, 1495, 1462, 1249, 1085; ${ }^{1} \mathrm{H}$ NMR $\left(400 \mathrm{MHz}, \mathrm{CDCl}_{3}\right) \delta 5.64(1 \mathrm{H}, \mathrm{s}, \mathrm{H} 3), 3.80(3 \mathrm{H}, \mathrm{s}, \mathrm{OMe})$, 2.80 ( $2 \mathrm{H}, \mathrm{t}, J 7.8), 1.57$ (2H, m, J 7.7), 1.36-1.27 (16H, br $\left.\mathrm{m},\left(\mathrm{CH}_{2}\right)_{8}\right), 0.89\left(3 \mathrm{H}, \mathrm{t}, J\right.$ 7.0, $\left.\mathrm{CH}_{3}\right) ;{ }^{13} \mathrm{C}$ NMR $(100 \mathrm{MHz}$, $\left.\mathrm{CDCl}_{3}\right) \delta 185.4(\mathrm{C} 4), 178.4\left(\mathrm{C} 2, \mathrm{q}, J_{\mathrm{CF}} 33\right), 116.8(\mathrm{C} 1, \mathrm{q}$, $\left.J_{\text {CF }} 292\right), 91.0(\mathrm{C} 3), 56.4(\mathrm{OMe}), 33.8,31.9,29.5,29.4$, 29.3, 29.2, 28.9, 26.9, $22.6\left(\mathrm{CH}_{2}\right), 13.9\left(\mathrm{CH}_{3}\right)$; HRMS (ESI) $m / z$, calcd. for $\mathrm{C}_{16} \mathrm{H}_{28} \mathrm{~F}_{3} \mathrm{O}_{2}[\mathrm{M}+\mathrm{H}]^{+}: 309.2041$, found: 309.2073; anal. calcd. for $\mathrm{C}_{16} \mathrm{H}_{27} \mathrm{~F}_{3} \mathrm{O}_{2}$ : C 62.32, H 8.83, found: C 62.30, H 8.89.

\section{1,1,1-Trifluoro-4-methoxyheptadec-3-en-2-one (3f)}

Yield 92\%, reddish oil; IR (film) $v_{\max } / \mathrm{cm}^{-1} 3090$, 2919, 2885, 1595, 1571, 1493, 1460, 1255, 1079; ${ }^{1} \mathrm{H}$ NMR $\left(400 \mathrm{MHz}, \mathrm{CDCl}_{3}\right) \delta 5.64(1 \mathrm{H}, \mathrm{s}, \mathrm{H} 3), 3.80(3 \mathrm{H}, \mathrm{s}, \mathrm{OMe})$, $2.80(2 \mathrm{H}, \mathrm{t}, J 7.8), 1.57$ (2H, m, J 7.7), 1.38-1.28 (20H, br $\left.\mathrm{m},\left(\mathrm{CH}_{2}\right)_{10}\right), 0.89(3 \mathrm{H}, \mathrm{t}, J 7.0) ;{ }^{13} \mathrm{C} \mathrm{NMR}\left(100 \mathrm{MHz}, \mathrm{CDCl}_{3}\right)$ $\delta 185.4(\mathrm{C} 4), 178.4\left(\mathrm{C} 2, \mathrm{q}, J_{\mathrm{CF}} 33\right), 116.8\left(\mathrm{C} 1, \mathrm{q}, J_{\mathrm{CF}} 292\right)$, 91.0 (C3), 56.4 (OMe), 33.9, 31.9, 29.64, 29.61, 29.5, 29.4, 29.38, 29.31, 29.2, 27.0, $22.7\left(\mathrm{CH}_{2}\right), 14.0(3 \mathrm{H}, \mathrm{t}, J$ 7.0, $\mathrm{CH}_{3}$ ); HRMS (ESI) $\mathrm{m} / z$, calcd. for $\mathrm{C}_{18} \mathrm{H}_{32} \mathrm{~F}_{3} \mathrm{O}_{2}[\mathrm{M}+\mathrm{H}]^{+}$: 337.2354, found: 337.2369; anal. calcd. for $\mathrm{C}_{18} \mathrm{H}_{32} \mathrm{~F}_{3} \mathrm{O}_{2}$ : C 64.26, H 9.29, found: C 64.35, H 9.42.

1,1,1-Trifluoro-4-methoxy-8-methylnon-3,7-dien-2-one (3g)

Yield 95\%, reddish oil; IR (film) $v_{\max } / \mathrm{cm}^{-1} 3089$, 2932, 2895, 1592, 1568, 1512, 1493, 1456, 1265, 1085; ${ }^{1} \mathrm{H}$ NMR $\left(400 \mathrm{MHz}, \mathrm{CDCl}_{3}\right) \delta 5.62(1 \mathrm{H}, \mathrm{s}, \mathrm{H} 3), 5.12$ $(1 \mathrm{H}, \mathrm{t}, J 7.6, \mathrm{H} 7), 3.78$ (3H, s, OMe), $2.82(2 \mathrm{H}, \mathrm{t}, J 7.8)$, $2.24\left(2 \mathrm{H}, \mathrm{q}, J\right.$ 7.7), $1.68\left(3 \mathrm{H}, \mathrm{s}, \mathrm{CH}_{3}\right), 1.61\left(3 \mathrm{H}, \mathrm{s}, \mathrm{CH}_{3}\right)$; ${ }^{13} \mathrm{C} \mathrm{NMR}\left(100 \mathrm{MHz}, \mathrm{CDCl}_{3}\right) \delta 184.6(\mathrm{C} 4), 178.4(\mathrm{C} 2, \mathrm{q}$, $\left.J_{\mathrm{CF}} 34\right), 133.1(\mathrm{C} 8), 122.3(\mathrm{C} 7), 116.7$ (C1, q, $\left.J_{\mathrm{CF}} 292\right), 91.1$ (C3), 56.4 (OMe), 33.9 (C5), $25.5\left(\mathrm{CH}_{3}\right), 25.3$ (C), 17.4 $\left(\mathrm{CH}_{3}\right)$; HRMS (ESI) $\mathrm{m} / z$, calcd. for $\mathrm{C}_{11} \mathrm{H}_{16} \mathrm{~F}_{3} \mathrm{O}_{2}[\mathrm{M}+\mathrm{H}]^{+}$: 237.1102, found: 237.1127; anal. calcd. for $\mathrm{C}_{11} \mathrm{H}_{15} \mathrm{~F}_{3} \mathrm{O}_{2}$ : C 55.93, H 6.40, found: C 56.08, H, 6.58.

\section{1,1,1-Trifluoro-4-methoxy-6-phenylhex-3-en-2-one (3h)}

Yield 95\%, reddish oil; IR (film) $v_{\max } / \mathrm{cm}^{-1} 3090,3075$, 2940, 2910, 1595, 1587, 1560, 1495, 1465, 1265, 1103, 1090; ${ }^{1} \mathrm{H}$ NMR (400 MHz, $\mathrm{CDCl}_{3}$ ) $\delta$ 7.35-7.23 (5H, m, Ph), $5.71(1 \mathrm{H}, \mathrm{s}, \mathrm{H} 3), 3.80(3 \mathrm{H}, \mathrm{s}, \mathrm{OMe}), 3.14\left(2 \mathrm{H}, \mathrm{m}, \mathrm{CH}_{2}\right)$, $2.91\left(2 \mathrm{H}, \mathrm{m}, \mathrm{CH}_{2}\right) ;{ }^{13} \mathrm{C} \mathrm{NMR}\left(100 \mathrm{MHz}, \mathrm{CDCl}_{3}\right) \delta 184.4$ (C4), $178.9\left(\mathrm{C} 2, \mathrm{q}, J_{\mathrm{CF}} 33\right), 140.8,128.8,126.6(\mathrm{Ph}), 117.1$ (C1, q, J JF 292), 91.7 (C3), $56.9(\mathrm{OMe}), 36.4\left(\mathrm{CH}_{2}\right), 33.3$ $\left(\mathrm{CH}_{2}\right)$; HRMS (ESI) $\mathrm{m} / z$, calcd. for $\mathrm{C}_{13} \mathrm{H}_{14} \mathrm{~F}_{3} \mathrm{O}_{2}[\mathrm{M}+\mathrm{H}]^{+}$: 259.0946, found: 259.1006; anal. calcd. for $\mathrm{C}_{13} \mathrm{H}_{13} \mathrm{~F}_{3} \mathrm{O}_{2}$ : C 60.46, H 5.07, found: C 60.45, H, 5.17. 
1,1,1-Trifluoro-4-methoxy-6-(4-hydroxyphenyl)hex-3-en2-one (3i)

Yield 93\%, reddish oil; IR (film) $v_{\max } / \mathrm{cm}^{-1} 3350,3070$, 2930, 2887, 1592, 1570, 1495, 1450, 1245, 1105, 1090; ${ }^{1} \mathrm{H}$ NMR (400 MHz, $\left.\mathrm{CDCl}_{3}\right) \delta 7.14(2 \mathrm{H}, \mathrm{d}, J$ 8.5, Ph), 6.78 $(2 \mathrm{H}, \mathrm{d}, J 8.5, \mathrm{Ph}), 5.67(1 \mathrm{H}, \mathrm{s}, \mathrm{H} 3), 3.80$ (3H, s, OMe), 3.07 $\left(2 \mathrm{H}, \mathrm{m}, \mathrm{CH}_{2}\right), 2.80\left(2 \mathrm{H}, \mathrm{m}, \mathrm{CH}_{2}\right) ;{ }^{13} \mathrm{C} \mathrm{NMR}(100 \mathrm{MHz}$, $\left.\mathrm{CDCl}_{3}\right) \delta 184.3(\mathrm{C} 4), 178.6\left(\mathrm{C} 2, \mathrm{q}, J_{\mathrm{CF}} 33\right), 154.8,132.6$, 129.6, $115.2(\mathrm{Ph}), 116.7\left(\mathrm{C} 1, \mathrm{q}, J_{\mathrm{CF}} 292\right), 91.4(\mathrm{C} 3), 56.6$ (OMe), $36.3\left(\mathrm{CH}_{2}\right), 32.1\left(\mathrm{CH}_{2}\right)$; HRMS (ESI) $\mathrm{m} / 2$, calcd. for $\mathrm{C}_{13} \mathrm{H}_{14} \mathrm{~F}_{3} \mathrm{O}_{3}[\mathrm{M}+\mathrm{H}]^{+}: 275.0895$, found: 275.0904; anal. calcd. for $\mathrm{C}_{13} \mathrm{H}_{13} \mathrm{~F}_{3} \mathrm{O}_{3}$ : C 56.94, H 4.78, found: C 57.10, H, 4.85 .

\section{1,1,1-Trifluoro-4-methoxy-6-(4-methoxyphenyl)hex-3-en-} 2-one (3j)

Yield 95\%, reddish oil; IR (film) $v_{\max } / \mathrm{cm}^{-1} 3089$, 2926, 2878, 1592, 1568, 1493, 1455, 1255, 1081; ${ }^{1} \mathrm{H}$ NMR $\left(400 \mathrm{MHz}, \mathrm{CDCl}_{3}\right) \delta 7.21(2 \mathrm{H}, \mathrm{d}, J 8.6, \mathrm{Ph}), 6.78(2 \mathrm{H}, \mathrm{d}$, $J$ 8.6, Ph), $5.70(1 \mathrm{H}, \mathrm{s}, \mathrm{H} 3), 3.82(3 \mathrm{H}, \mathrm{s}, \mathrm{OMe}), 3.80(3 \mathrm{H}$, $\mathrm{s}, \mathrm{OMe}), 3.10\left(2 \mathrm{H}, \mathrm{m}, \mathrm{CH}_{2}\right), 2.85\left(2 \mathrm{H}, \mathrm{m}, \mathrm{CH}_{2}\right) ;{ }^{13} \mathrm{C} \mathrm{NMR}$ $\left(100 \mathrm{MHz}, \mathrm{CDCl}_{3}\right) \delta 184.2(\mathrm{C} 4), 178.5\left(\mathrm{C} 2, \mathrm{q}, J_{\mathrm{CF}} 33\right)$, $158.1,132.5,129.4,113.8(\mathrm{Ph}), 116.7\left(\mathrm{C} 1, \mathrm{q}, J_{\mathrm{CF}} 292\right), 91.3$ (C3), $56.5(\mathrm{OMe}), 55.2(\mathrm{OMe}), 36.3\left(\mathrm{CH}_{2}\right), 32.1\left(\mathrm{CH}_{2}\right)$; ${ }^{19} \mathrm{~F} \mathrm{NMR}\left(376 \mathrm{MHz}, \mathrm{CDCl}_{3}\right) \delta-78.1\left(\mathrm{CF}_{3}\right)$; HRMS (ESI) $m / z$, calcd. for $\mathrm{C}_{14} \mathrm{H}_{16} \mathrm{~F}_{3} \mathrm{O}_{3}[\mathrm{M}+\mathrm{H}]^{+}: 289.1052$, found: 289.1077; anal. calcd. for $\mathrm{C}_{14} \mathrm{H}_{15} \mathrm{~F}_{3} \mathrm{O}_{2}$ : C 58.33, H 5.25, found: C 58.35, H 5.30.

\section{1,1,1-Trifluoro-4-methoxy-5-(methylthio)hex-3-en-2-one} (3k)

Yield 95\%, yellow oil; IR (film) $v_{\max } / \mathrm{cm}^{-1} 3085,2950$, 2895, 2870, 1592, 1575, 1495, 1455, 1255, 1107, 1090; ${ }^{1} \mathrm{H}$ NMR $\left(400 \mathrm{MHz}, \mathrm{CDCl}_{3}\right) \delta 5.58(1 \mathrm{H}, \mathrm{s}, \mathrm{H} 3), 4.95(1 \mathrm{H}$, q, J 7.0, H5), 3.78 (3H, s, OMe), $2.04\left(3 \mathrm{H}, \mathrm{s}, \mathrm{SCH}_{3}\right), 1.35$ $\left(3 \mathrm{H}, \mathrm{d}, \mathrm{CH}_{3}\right) ;{ }^{13} \mathrm{C} \mathrm{NMR}\left(100 \mathrm{MHz}, \mathrm{CDCl}_{3}\right) \delta 182.8(\mathrm{C} 4)$, $178.1\left(\mathrm{C} 2, \mathrm{q}, J_{\mathrm{CF}} 34\right), 117.4\left(\mathrm{C} 1, \mathrm{q}, J_{\mathrm{CF}} 295\right), 90.6(\mathrm{C} 3)$, 56.8 (OMe), 39.2 (C5), 16.8 (C6), $14.1\left(\mathrm{SCH}_{3}\right) ;{ }^{19} \mathrm{~F} \mathrm{NMR}$ $\left(376 \mathrm{MHz}, \mathrm{CDCl}_{3}\right) \delta-78.1\left(\mathrm{CF}_{3}\right)$; HRMS (ESI) $\mathrm{m} / z$, calcd. for $\mathrm{C}_{8} \mathrm{H}_{12} \mathrm{~F}_{3} \mathrm{O}_{2} \mathrm{~S}[\mathrm{M}+\mathrm{H}]^{+}: 229.0510$, found: 229.0538; anal. calcd. for $\mathrm{C}_{8} \mathrm{H}_{11} \mathrm{~F}_{3} \mathrm{O}_{2} \mathrm{~S}$ : C 42.10, H 4.86, found: C 42.17, H 4.78.

\section{1,1,1-Trifluoro-4-methoxy-5-(2-methoxyphenyl)pent-3-en-} 2-one (3I)

Yield 93\%, yellowish oil; IR (film) $v_{\max } / \mathrm{cm}^{-1} 3090$, 3080, 2946, 2910, 2885, 1596, 1570, 1495, 1460, 1258, 1102, 1091; ${ }^{\mathrm{H}} \mathrm{NMR}\left(400 \mathrm{MHz}, \mathrm{CDCl}_{3}\right) \delta 7.22(1 \mathrm{H}, \mathrm{m}$, $\mathrm{Ph}), 7.06$ (1H, m, Ph), 6.85 (2H, m, Ph), 5.74 (1H, s, H3), 4.22 (2H, s, H5), 3.77 (3H, s, OMe), 3.65 (3H, s, OMe); ${ }^{13} \mathrm{C}$ NMR $\left(100 \mathrm{MHz}, \mathrm{CDCl}_{3}\right) \delta 182.4(\mathrm{C} 4), 178.5(\mathrm{C} 2$, $\left.\mathrm{q}, J_{\mathrm{CF}} 33\right), 157.6,132.6,129.6,115.2(\mathrm{Ph}), 116.7(\mathrm{C} 1, \mathrm{q}$, $\left.J_{\mathrm{CF}} 292\right), 91.4(\mathrm{C} 3), 56.6(\mathrm{OMe}), 36.3\left(\mathrm{CH}_{2}\right), 32.1\left(\mathrm{CH}_{2}\right)$; ${ }^{19} \mathrm{~F} \mathrm{NMR}\left(376 \mathrm{MHz}, \mathrm{CDCl}_{3}\right) \delta-78.1\left(\mathrm{CF}_{3}\right)$; HRMS (ESI) $m / z$, calcd. for $\mathrm{C}_{13} \mathrm{H}_{14} \mathrm{~F}_{3} \mathrm{O}_{3}[\mathrm{M}+\mathrm{H}]^{+}:$275.0895, found: 275.0916; anal. calcd. for $\mathrm{C}_{13} \mathrm{H}_{13} \mathrm{~F}_{3} \mathrm{O}_{3}: \mathrm{C}$ 56.94, $\mathrm{H}$ 4.78, found: C 57.10, H 4.85 .

Methyl 7,7,7-trifluoro-4-methoxy-6-oxohept-4-enoate (3m)

Yield 90\%, yellowish oil; IR (film) $v_{\max } / \mathrm{cm}^{-1} 3090$, 3045, 2936, 2885, 1690, 1592, 1570, 1495, 1460, 1270, 1120, 1085; ${ }^{1} \mathrm{H}$ NMR (400 MHz, $\left.\mathrm{CDCl}_{3}\right) \delta 5.73(1 \mathrm{H}, \mathrm{s}$, H5), 3.83 (3H, s, OMe), 3.67 (3H, s, OMe), 3.16 (2H, m, $\left.\mathrm{CH}_{2}\right), 2.59\left(2 \mathrm{H}, \mathrm{m}, \mathrm{CH}_{2}\right) ;{ }^{13} \mathrm{C} \mathrm{NMR}\left(100 \mathrm{MHz}, \mathrm{CDCl}_{3}\right)$ $\delta 182.3(\mathrm{C} 4), 178.3$ (C6, q, $\left.J_{\mathrm{CF}} 33\right), 172.2(\mathrm{C} 1), 116.8$ (C7, q, $\left.J_{\mathrm{CF}} 292\right), 91.3$ (C5), $56.6(\mathrm{OMe}), 51.4(\mathrm{OMe}), 29.8$ $\left(\mathrm{CH}_{2}\right), 29.0\left(\mathrm{CH}_{2}\right) ;{ }^{19} \mathrm{~F}$ NMR $\left(376 \mathrm{MHz}, \mathrm{CDCl}_{3}\right) \delta-78.1$ $\left(\mathrm{CF}_{3}\right)$; HRMS (ESI) $\mathrm{m} / z$, calcd. for $\mathrm{C}_{9} \mathrm{H}_{12} \mathrm{~F}_{3} \mathrm{O}_{4}[\mathrm{M}+\mathrm{H}]^{+}$: 241.0688, found: 241.0747; anal. calcd. for $\mathrm{C}_{9} \mathrm{H}_{11} \mathrm{~F}_{3} \mathrm{O}_{4}$ : C 45.01, H 4.62, found: C 45.20, H 4.70.

Methyl 8,8,8-trifluoro-5-methoxy-7-oxooct-5-enoate (3n)

Yield 91\%, yellow oil; IR (film) $v_{\max } / \mathrm{cm}^{-1} 3090,3045$, 2940, 2885, 1688, 1595, 1570, 1495, 1480, 1267, 1115, 1080; ${ }^{1} \mathrm{H}$ NMR $\left(400 \mathrm{MHz}, \mathrm{CDCl}_{3}\right) \delta 5.66(1 \mathrm{H}, \mathrm{s}, \mathrm{H} 3), 3.80(3 \mathrm{H}$, s, OMe), $3.68(3 \mathrm{H}, \mathrm{s}, \mathrm{OMe}), 2.86\left(2 \mathrm{H}, \mathrm{m}, \mathrm{CH}_{2}\right), 2.38(2 \mathrm{H}$, t, $\left.\mathrm{CH}_{2}\right), 1.91\left(2 \mathrm{H}, \mathrm{m}, \mathrm{CH}_{2}\right) ;{ }^{13} \mathrm{C} \mathrm{NMR}\left(100 \mathrm{MHz}, \mathrm{CDCl}_{3}\right)$ $\delta 182.3(\mathrm{C} 5), 178.4\left(\mathrm{C} 7, \mathrm{q}, J_{\mathrm{CF}} 33\right), 172.4(\mathrm{C} 1), 116.8(\mathrm{C} 8, \mathrm{q}$, $\left.J_{\mathrm{CF}} 292\right), 91.3(\mathrm{C} 6), 56.6(\mathrm{OMe}), 51.3(\mathrm{OMe}), 29.9(\mathrm{C} 4), 29.2$ (C2), $19.1(\mathrm{C} 3) ;{ }^{19} \mathrm{~F} \mathrm{NMR}\left(376 \mathrm{MHz}, \mathrm{CDCl}_{3}\right) \delta-78.0(3 \mathrm{~F}$, $\mathrm{s}, \mathrm{CF}_{3}$ ); HRMS (ESI) $\mathrm{m} / \mathrm{z}$, calcd. for $\mathrm{C}_{10} \mathrm{H}_{13} \mathrm{~F}_{3} \mathrm{O}_{4}[\mathrm{M}+\mathrm{H}]^{+}$: 255.0844, found: 255.0898; anal. calcd. for $\mathrm{C}_{11} \mathrm{H}_{15} \mathrm{~F}_{3} \mathrm{O}_{2}$ : C 47.25, H 5.15, found: C 47.47, H 5.30.

Methyl 7-chloro-7,7-difluoro-4-methoxy-6-oxohept-4-enoate (7m)

Yield 90\%, yellowish oil; IR (film) $v_{\max } / \mathrm{cm}^{-1} 3087$, 3046, 2943, 2882, 1687, 1591, 1570, 1496, 1458, 1270, 1120,$1085 ;{ }^{1} \mathrm{H}$ NMR $\left(400 \mathrm{MHz}, \mathrm{CDCl}_{3}\right) \delta 5.71(1 \mathrm{H}, \mathrm{s}$, $\mathrm{H} 5), 3.82$ (3H, s, OMe), 3.69 (3H, s, OMe), 3.16 (2H, m, $\left.\mathrm{CH}_{2}\right), 2.59\left(2 \mathrm{H}, \mathrm{m}, \mathrm{CH}_{2}\right) ;{ }^{13} \mathrm{C}$ NMR (100 MHz, $\left.\mathrm{CDCl}_{3}\right)$ $\delta 182.1(\mathrm{C} 4), 179.6\left(\mathrm{C} 6, \mathrm{t}, J_{\mathrm{CF}} 27\right), 172.3(\mathrm{C} 1), 120.6(\mathrm{C} 7$, $\left.\mathrm{t}, J_{\mathrm{CF}} 306\right), 90.5(\mathrm{C} 5), 56.7(\mathrm{OMe}), 51.4(\mathrm{OMe}), 29.9\left(\mathrm{CH}_{2}\right)$, $29.0\left(\mathrm{CH}_{2}\right) ;{ }^{19} \mathrm{~F}$ NMR $\left(376 \mathrm{MHz}, \mathrm{CDCl}_{3}\right) \delta-65.0(2 \mathrm{~F}, \mathrm{~s}$, $\mathrm{CClF}_{2}$ ); $\mathrm{HRMS}$ (ESI) $\mathrm{m} / \mathrm{z}$, calcd. for $\mathrm{C}_{9} \mathrm{H}_{12} \mathrm{ClF}_{2} \mathrm{O}_{4}[\mathrm{M}+\mathrm{H}]^{+}$: 257.0392, found: 257.0435; anal. calcd. for $\mathrm{C}_{9} \mathrm{H}_{11} \mathrm{ClF}_{2} \mathrm{O}_{4}$ : C 42.12, H 4.32, found: C 42.17, H 4.30.

1,1,1-Trichloro-4-methoxy-8-methylnon-3,7-dien-2-one (4g)

Yield 95\%, reddish oil; IR (film) $v_{\max } / \mathrm{cm}^{-1} 3092$, 3075, 2926, 2883, 1592, 1580, 1495, 1458, 1265, 1118, 1091; ${ }^{1} \mathrm{H}$ NMR $\left(400 \mathrm{MHz}, \mathrm{CDCl}_{3}\right) \delta 5.62(1 \mathrm{H}, \mathrm{s}, \mathrm{H} 3), 5.12$ 
(1H, t, J 7.6, H7), 3.78 (3H, s, OMe), $2.82(2 \mathrm{H}, \mathrm{t}, J 7.8)$, $2.24\left(2 \mathrm{H}, \mathrm{q}, J\right.$ 7.7), $1.68\left(3 \mathrm{H}, \mathrm{s}, \mathrm{CH}_{3}\right), 1.61\left(3 \mathrm{H}, \mathrm{s}, \mathrm{CH}_{3}\right)$; ${ }^{13} \mathrm{C}$ NMR $\left(100 \mathrm{MHz}, \mathrm{CDCl}_{3}\right) \delta 184.6(\mathrm{C} 4), 178.4(\mathrm{C} 2, \mathrm{q}$, $\left.J_{\mathrm{CF}} 34\right), 133.1(\mathrm{C} 8), 122.3(\mathrm{C} 7), 116.7$ (C1, q, $\left.J_{\mathrm{CF}} 292\right), 91.1$ (C3), 56.4 (OMe), 33.9 (C5), $25.5\left(\mathrm{CH}_{3}\right), 25.3$ (C6), 17.4 $\left(\mathrm{CH}_{3}\right)$; HRMS (ESI) $\mathrm{m} / z$, calcd. for $\mathrm{C}_{11} \mathrm{H}_{16} \mathrm{Cl}_{3} \mathrm{O}_{2}[\mathrm{M}+\mathrm{H}]^{+}$: 285.0216, 287.0286, found: 285.0234, 287.0278; anal. calcd. for $\mathrm{C}_{11} \mathrm{H}_{15} \mathrm{Cl}_{3} \mathrm{O}_{2}$ : C 46.26, H 5.29, found: C 46.30, H 5.43.

\section{1,1,1-Trichloro-4-methoxy-6-phenylhex-3-en-2-one (4h)}

Yield 95\%, reddish oil; IR (film) $v_{\max } / \mathrm{cm}^{-1} 3093,2945$, 2889, 1592, 1572, 1493, 1453, 1261, 1107, 1081; ${ }^{1} \mathrm{H}$ NMR $\left(400 \mathrm{MHz}, \mathrm{CDCl}_{3}\right) \delta$ 7.35-7.23 (5H, m, Ph), $5.71(1 \mathrm{H}, \mathrm{s}$, $\mathrm{H} 3), 3.80(3 \mathrm{H}, \mathrm{s}, \mathrm{OMe}), 3.14\left(2 \mathrm{H}, \mathrm{m}, \mathrm{CH}_{2}\right), 2.91(2 \mathrm{H}, \mathrm{m}$, $\left.\mathrm{CH}_{2}\right) ;{ }^{13} \mathrm{C} \mathrm{NMR}\left(100 \mathrm{MHz}, \mathrm{CDCl}_{3}\right) \delta 184.4(\mathrm{C} 4), 178.9(\mathrm{C} 2$, $\left.\mathrm{q}, J_{\mathrm{CF}} 33\right), 140.8,128.8,126.6(\mathrm{Ph}), 117.1\left(\mathrm{C} 1, \mathrm{q}, J_{\mathrm{CF}} 292\right)$, 91.7 (C3), 56.9 (OMe), $36.4\left(\mathrm{CH}_{2}\right), 33.3\left(\mathrm{CH}_{2}\right)$; HRMS (ESI) $\mathrm{m} / z$, calcd. for $\mathrm{C}_{13} \mathrm{H}_{14} \mathrm{Cl}_{3} \mathrm{O}_{2}[\mathrm{M}+\mathrm{H}]^{+}:$307.0059, 309.0030, found: 307.0107, 309.0081; anal. calcd. for $\mathrm{C}_{13} \mathrm{H}_{13} \mathrm{Cl}_{3} \mathrm{O}_{2}$ : C 50.76, H 4.26, found: C 50.60, H 4.30.

1,1,1-Trichloro-4-methoxy-5-(methylthio)hex-3-en-2-one (4k)

Yield 95\%, yellow oil; IR (film) $v_{\max } / \mathrm{cm}^{-1} 3089,2926$, $2878,1592,1568,1493,1455,1255,1081 ;{ }^{1} \mathrm{H}$ NMR $\left(400 \mathrm{MHz}, \mathrm{CDCl}_{3}\right) \delta 5.58(1 \mathrm{H}, \mathrm{s}, \mathrm{H} 3), 4.95(1 \mathrm{H}, \mathrm{q}, J 7.0$, $\mathrm{H} 5), 3.78(3 \mathrm{H}, \mathrm{s}, \mathrm{OMe}), 2.04\left(3 \mathrm{H}, \mathrm{s}, \mathrm{SCH}_{3}\right), 1.35(3 \mathrm{H}, \mathrm{d}$, $\left.\mathrm{CH}_{3}\right) ;{ }^{13} \mathrm{C}$ NMR (100 MHz, $\left.\mathrm{CDCl}_{3}\right) \delta 182.8(\mathrm{C} 4), 178.1$ (C2, q, $\left.J_{\mathrm{CF}} 34\right), 117.4$ (C1, q, $\left.J_{\mathrm{CF}} 295\right), 90.6$ (C3), 56.8 (OMe), 39.2 (C5), 16.8 (C6), $14.1\left(\mathrm{SCH}_{3}\right)$; HRMS (ESI) $\mathrm{m} / z$, calcd. for $\mathrm{C}_{8} \mathrm{H}_{11} \mathrm{Cl}_{3} \mathrm{O}_{2} \mathrm{~S}[\mathrm{M}+\mathrm{H}]^{+}: 276.9624,278.9594$, found: 276.9686, 278.9658; anal. calcd. for $\mathrm{C}_{8} \mathrm{H}_{11} \mathrm{Cl}_{3} \mathrm{O}_{2} \mathrm{~S}$ : C 34.62, H 3.99, found: C 34.55, H 4.00.

Methyl 7,7,7-trichloro-4-methoxy-6-oxohept-4-enoate (4m)

Yield 90\%, yellowish oil; IR (film) $v_{\max } / \mathrm{cm}^{-1} 3089$, 2935, 2880, 1728, 1595, 1570, 1490, 1470, 1265, 1120, $1085 ;{ }^{1} \mathrm{H}$ NMR (400 MHz, $\left.\mathrm{CDCl}_{3}\right) \delta 5.73(1 \mathrm{H}, \mathrm{s}, \mathrm{H} 5), 3.83$ $(3 \mathrm{H}, \mathrm{s}, \mathrm{OMe}), 3.67(3 \mathrm{H}, \mathrm{s}, \mathrm{OMe}), 3.16\left(2 \mathrm{H}, \mathrm{m}, \mathrm{CH}_{2}\right), 2.59$ $\left(2 \mathrm{H}, \mathrm{m}, \mathrm{CH}_{2}\right) ;{ }^{13} \mathrm{C} \mathrm{NMR}\left(100 \mathrm{MHz}, \mathrm{CDCl}_{3}\right) \delta 182.3(\mathrm{C} 4)$, 178.3 (C6, q, $\left.J_{\mathrm{CF}} 33\right), 172.2(\mathrm{C} 1), 116.8\left(\mathrm{C} 7, \mathrm{q}, J_{\mathrm{CF}} 292\right)$, 91.3 (C5), 56.6 (OMe), $51.4(\mathrm{OMe}), 29.8\left(\mathrm{CH}_{2}\right), 29.0$ $\left(\mathrm{CH}_{2}\right)$; HRMS (ESI) $m / z$, calcd. for $\mathrm{C}_{9} \mathrm{H}_{12} \mathrm{Cl}_{3} \mathrm{O}_{4}[\mathrm{M}+\mathrm{H}]^{+}$: 288.9801, 290.9772, found: 288.9863, 290.9835; anal. calcd. for $\mathrm{C}_{9} \mathrm{H}_{11} \mathrm{~F}_{3} \mathrm{O}_{4}$ : C 64.07, H 7.59, found: C 45.27, H 2.68 .

\section{3-(Ethoxymethylene)-1,1,1-trihalotridecan-2-ones}

To a stirred solution of diethoxy acetal derived from precursor aldehyde $2 \mathbf{v}(30 \mathrm{mmol})$ and pyridine $(60 \mathrm{mmol}$,
$4.8 \mathrm{~g})$ in $\mathrm{CHCl}_{3}(30 \mathrm{~mL})$ kept at $0{ }^{\circ} \mathrm{C}$, a solution of acylating reagent $(60 \mathrm{mmol}: 8.4 \mathrm{~mL}$ trifluoroacetic anhydride, $10.5 \mathrm{~mL}$ chlorodifluoroacetic anhydride or $6.8 \mathrm{~mL}$ trichloroacetyl chloride) in $\mathrm{CHCl}_{3}(20 \mathrm{~mL})$ was added dropwise at -5 to $10{ }^{\circ} \mathrm{C}$. Then the mixture was stirred for $12-24 \mathrm{~h}$ under reflux $\left(60{ }^{\circ} \mathrm{C}\right)$. After the mixture was quenched with a $2 \mathrm{M} \mathrm{HCl}$ solution $(20 \mathrm{~mL})$, the organic layer was separated and washed twice with water and dried with $\mathrm{Na}_{2} \mathrm{SO}_{4}$. The solvent was evaporated, and the residue was distilled to remove methyl trihaloacetate byproducts. The products $3 \mathbf{v}, \mathbf{4 v}$, and $\mathbf{7 v}$ were obtained as reddish to black oil with high purity.

\section{3-(Ethoxymethylene)-1,1,1-trifluorotridecan-2-one (3v)}

Yield 90\%, reddish oil; IR (film) $v_{\max } / \mathrm{cm}^{-1} 2995$, 2926, 2878, 1765, 1587, 1495, 1460, 1245, 1181; ${ }^{1} \mathrm{H}$ NMR $\left(400 \mathrm{MHz}, \mathrm{CDCl}_{3}\right) \delta 7.51(1 \mathrm{H}, \mathrm{s}, \mathrm{H} 14), 4.20(2 \mathrm{H}, \mathrm{q}$, $\left.J 6.9, \mathrm{OCH}_{2}\right), 2.32(2 \mathrm{H}, \mathrm{t}, J 7.5, \mathrm{H} 4), 1.39(3 \mathrm{H}, \mathrm{t}, J 6.8$, $\left.\mathrm{CH}_{3}\right), 1.30-1.24\left(16 \mathrm{H}, \mathrm{m}, \mathrm{CH}_{2}\right), 0.88(3 \mathrm{H}, \mathrm{t}, J$ 6.5, H13); ${ }^{13} \mathrm{C} \mathrm{NMR}\left(100 \mathrm{MHz}, \mathrm{CDCl}_{3}\right) \delta 179.7$ (C2, q, $\left.J_{\mathrm{CF}} 34\right), 164.2$ (C14, q, $\left.J_{\mathrm{CF}} 5.0\right), 117.1(\mathrm{C} 3), 117.0$ (C1, q, $\left.J_{\mathrm{CF}} 291\right), 71.5$ $\left(\mathrm{OCH}_{2}\right), 31.9,29.55,29.5,29.3,29.29,29.2,27.9,22.8$, $22.6\left(\mathrm{CH}_{2}\right), 15.1\left(\mathrm{CH}_{3}\right), 13.9\left(\mathrm{CH}_{3}\right) ;{ }^{19} \mathrm{~F} \mathrm{NMR}(376 \mathrm{MHz}$, $\left.\mathrm{CDCl}_{3}\right) \delta-78.3\left(\mathrm{CF}_{3}\right)$; HRMS (ESI) $\mathrm{m} / z$, calcd. for $\mathrm{C}_{16} \mathrm{H}_{28} \mathrm{~F}_{3} \mathrm{O}_{2}[\mathrm{M}+\mathrm{H}]^{+}:$309.2041, found: 309.2102; anal. calcd. for $\mathrm{C}_{16} \mathrm{H}_{27} \mathrm{~F}_{3} \mathrm{O}_{2}$ : C 62.32, H 8.83, found: C 62.55, H 8.80 .

\section{1,1,1-Trichloro-3-(ethoxymethylene)tridecan-2-one (4v)}

Yield 91\%, black oil; IR (film) $v_{\max } / \mathrm{cm}^{-1} 2995,2923$, $2875,1749,1586,1495,1460,1254,1145 ;{ }^{1} \mathrm{H}$ NMR $\left(400 \mathrm{MHz}, \mathrm{CDCl}_{3}\right) \delta 7.99(1 \mathrm{H}, \mathrm{s}, \mathrm{H} 14), 4.18(2 \mathrm{H}, \mathrm{q}, J 7.2$, $\left.\mathrm{OCH}_{2}\right), 2.39(2 \mathrm{H}, \mathrm{t}, J 7.6, \mathrm{H} 4), 1.40\left(3 \mathrm{H}, \mathrm{t}, J\right.$ 7.2, $\left.\mathrm{CH}_{3}\right)$, 1.30-1.27 (16H, m, $\left.\mathrm{CH}_{2}\right), 0.90$ (3H, t, J 6.8, H13); ${ }^{13} \mathrm{C} \mathrm{NMR}$ $\left(100 \mathrm{MHz}, \mathrm{CDCl}_{3}\right) \delta 181.1(\mathrm{C} 2), 163.5$ (C14), 112.5 (C3), 96.7 (C1), $70.9\left(\mathrm{OCH}_{2}\right), 31.8,29.55,29.5,29.38,29.35$, 29.3, 28.1, 24.7, $22.6\left(\mathrm{CH}_{2}\right), 15.4\left(\mathrm{CH}_{3}\right), 14.0\left(\mathrm{CH}_{3}\right)$; HRMS (ESI) $\mathrm{m} / z$, calcd. for $\mathrm{C}_{16} \mathrm{H}_{28} \mathrm{Cl}_{3} \mathrm{O}_{2}[\mathrm{M}+\mathrm{H}]^{+}: 357.1155$, 359.1125, found: $357.1205,359.1173$; anal. calcd. for $\mathrm{C}_{16} \mathrm{H}_{27} \mathrm{Cl}_{3} \mathrm{O}_{2}$ : C 53.72, H 7.61, found: C 53.60, H 7.60.

1-Chloro-3-(ethoxymethylene)-1,1-difluorotridecan-2-one (7v)

Yield 90\%, reddish oil; IR (film) $v_{\max } / \mathrm{cm}^{-1} 2995$, 2930, 2878, 1758, 1586, 1495, 1460, 1250, 1150; ${ }^{1} \mathrm{H}$ NMR $\left(400 \mathrm{MHz}, \mathrm{CDCl}_{3}\right) \delta 7.63(1 \mathrm{H}, \mathrm{s}, \mathrm{H} 14), 4.18(2 \mathrm{H}, \mathrm{q}, J 7.0$, $\left.\mathrm{OCH}_{2}\right), 2.34(2 \mathrm{H}, \mathrm{t}, J 7.4, \mathrm{H} 4), 1.40\left(3 \mathrm{H}, \mathrm{t}, J\right.$ 7.2, $\left.\mathrm{CH}_{3}\right)$, 1.30-1.27 (16H, m, $\left.\mathrm{CH}_{2}\right), 0.90$ (3H, t, J 7.0, H13); ${ }^{13} \mathrm{C} \mathrm{NMR}$ $\left(100 \mathrm{MHz}, \mathrm{CDCl}_{3}\right) \delta 180.9\left(\mathrm{C} 2, \mathrm{t}, J_{\mathrm{CF}} 34\right), 163.8(\mathrm{C} 14, \mathrm{t}$, $\left.J_{\mathrm{CF}} 6.3\right), 120.8\left(\mathrm{C} 1, \mathrm{t}, J_{\mathrm{CF}} 305\right), 115.6(\mathrm{C} 3), 71.3\left(\mathrm{OCH}_{2}\right)$, $31.8,29.57,29.5,29.35,29.3,29.2,27.9,23.2,22.6$ 
$\left(\mathrm{CH}_{2}\right), 15.3\left(\mathrm{CH}_{3}\right), 14.0\left(\mathrm{CH}_{3}\right)$; HRMS (ESI) $\mathrm{m} / z$, calcd. for $\mathrm{C}_{16} \mathrm{H}_{28} \mathrm{ClF}_{2} \mathrm{O}_{2}[\mathrm{M}+\mathrm{H}]^{+}$: 325.1746, found: 325.1793 ; anal. calcd. for $\mathrm{C}_{16} \mathrm{H}_{27} \mathrm{~F}_{2} \mathrm{ClO}_{2}$ : C 59.16, H 8.38, found: C 59.20, H 8.25.

1,1,1-Trihaloalkan-2,4-diones from hydrolysis of 1,1,1-trihalo4-methoxy-3-alken-2-ones

To a solution of the isolated 1,1,1-trihalo-4-methoxy3 -alken-2-one $\mathbf{3 h}$-k or $\mathbf{4 h}, \mathbf{k}(15 \mathrm{mmol})$ in $25 \mathrm{~mL}$ chloroform, a mixture of $50 \mathrm{~mL} 3 \mathrm{~mol} \mathrm{~L}^{-1} \mathrm{H}_{2} \mathrm{SO}_{4}$ was added and stirred at reflux for 4 to $8 \mathrm{~h}$. Then the organic layer was separated and washed with deionized water $(3 \times 15 \mathrm{~mL})$. The organic layer was dried (anhydrous $\mathrm{Na}_{2} \mathrm{SO}_{4}$ ) and evaporated in a rotary evaporator under vacuum to get the respective 1,1,1-trihaloalkan-2,4-diones $\mathbf{5 h}-\mathbf{k}$ and $\mathbf{6 h}, \mathbf{k}$ in quantitative yields (>90\%).

\section{One-pot procedure}

A solution of acylating agent (trifluoromethyl anhydride or trichloroacetyl chloride, $60 \mathrm{mmol}$ ) in chloroform $(20 \mathrm{~mL})$ was added dropwise to a stirred solution of dimethoxy-acetals, pyridine $(5.2 \mathrm{~mL}, 60 \mathrm{mmol})$. The mixture was stirred for $8 \mathrm{~h}$ at $0-25^{\circ} \mathrm{C}$, quenched with a 3 mol L-1 $\mathrm{H}_{2} \mathrm{SO}_{4}$ solution ( $50 \mathrm{~mL}$ ), and then stirred at reflux for 4 to $8 \mathrm{~h}\left(85^{\circ} \mathrm{C}\right)$. The organic layer was dried (anhydrous $\mathrm{Na}_{2} \mathrm{SO}_{4}$ ), the solvent was evaporated, and products were obtained in quantitative yields (>90\%).

\section{1,1,1-Trifluoro-6-phenylhexan-2,4-dione (5h)}

Yield 95\%, reddish oil; IR (film) $v_{\max } / \mathrm{cm}^{-1} 3412,3375$, 3064, 2940, 2910, 1777, 1774, 1650, 1570, 1515, 1305, 1265, 1103, 1090; ${ }^{1} \mathrm{H}$ NMR (400 MHz, $\left.\mathrm{CDCl}_{3}\right) \delta 7.35(\mathrm{~m}$, 2H, Ph), 7.27 (m, 3H, Ph), 5.93 (s, 1H, H3), 3.03 (t, 2H, $\left.\mathrm{CH}_{2}\right), 2.81\left(\mathrm{~m}, 2 \mathrm{H}, \mathrm{CH}_{2}\right) ;{ }^{13} \mathrm{C} \mathrm{NMR}\left(100 \mathrm{MHz}, \mathrm{CDCl}_{3}\right)$ $\delta 196.5$ (C4), 174.8 (q, $\left.J_{\mathrm{CF}} 36, \mathrm{C} 2\right), 139.6,128.7,128.2$, $126.6(\mathrm{Ph}), 117.1$ (q, $\left.J_{\mathrm{CF}} 282, \mathrm{C} 1\right), 96.2$ (q, $\left.J_{\mathrm{CF}} 2, \mathrm{C} 3\right), 36.4$ $\left(\mathrm{CH}_{2}\right), 33.3\left(\mathrm{CH}_{2}\right) ;{ }^{19} \mathrm{~F}$ NMR $\left(376 \mathrm{MHz}, \mathrm{CDCl}_{3}\right) \delta-76.5$ $\left(\mathrm{CF}_{3}\right)$; HRMS (ESI) $\mathrm{m} / \mathrm{z}$, calcd. for $\mathrm{C}_{12} \mathrm{H}_{10} \mathrm{~F}_{3} \mathrm{O}_{2}^{-}[\mathrm{M}-1]^{-}$: 243.0638, found: 243.0706 .

\section{1,1,1-Trifluoro-6-(4-hydroxyphenyl)hexan-2,4-dione (5i)}

Yield 85\%, reddish oil; IR (film) $v_{\max } / \mathrm{cm}^{-1} 3415,3380$, 3350, 3070, 2930, 2886, 1590, 1570, 1495, 1450, 1245, 1105, 1090; ${ }^{1} \mathrm{H}$ NMR (400 MHz, $\left.\mathrm{CDCl}_{3}\right) \delta 7.09(2 \mathrm{H}, \mathrm{m}$, Ar), 6.79 (2H, m, Ar), 5.90 (1H, s, H3), 2.93 (2H, m, $\mathrm{CH}_{2}$ ), $2.74\left(2 \mathrm{H}, \mathrm{m}, \mathrm{CH}_{2}\right) ;{ }^{13} \mathrm{C} \mathrm{NMR}\left(100 \mathrm{MHz}, \mathrm{CDCl}_{3}\right) \delta 196.5$ (C4), 175.0 (q, $\left.J_{\mathrm{CF}} 36, \mathrm{C} 2\right), 154.3,129.3,115.6$ (Ar), 115.5 $(\mathrm{Ph}), 117.0$ (q, $\left.J_{\mathrm{CF}} 281, \mathrm{C} 1\right), 91.4(\mathrm{q}, J 2, \mathrm{C} 3), 40.5\left(\mathrm{CH}_{2}\right)$, $30.4\left(\mathrm{CH}_{2}\right) ;{ }^{19} \mathrm{~F}$ NMR $\left(376 \mathrm{MHz}, \mathrm{CDCl}_{3}\right) \delta-76.7\left(\mathrm{CF}_{3}\right)$;
HRMS (ESI) $m / z$, calcd. for $\mathrm{C}_{12} \mathrm{H}_{10} \mathrm{~F}_{3} \mathrm{O}_{3}[\mathrm{M}-1]^{-}: 259.0588$, found: 259.0649 .

\section{1,1,1-Trifluoro-6-(4-methoxyphenyl)hexan-2,4-dione (5j)}

Yield 92\%, reddish oil; IR (film) $v_{\max } / \mathrm{cm}^{-1} 3415,3350$, 3075, 2930, 2886, 1590, 1570, 1493, 1455, 1255, 1110. 1085; ${ }^{1} \mathrm{H}$ NMR (400 MHz, $\mathrm{CDCl}_{3}$ ) $\delta 7.13$ (2H, m, Ar), 6.88 (2H, m, Ar), 5.91 (1H, s, H3), 3.81 (3H, s, OMe), 2.95 $\left(2 \mathrm{H}, \mathrm{m}, \mathrm{CH}_{2}\right), 2.75\left(2 \mathrm{H}, \mathrm{m}, \mathrm{CH}_{2}\right) ;{ }^{13} \mathrm{C} \mathrm{NMR}(100 \mathrm{MHz}$, $\left.\mathrm{CDCl}_{3}\right) \delta 196.5(\mathrm{C} 4), 175.0\left(\mathrm{q}, J_{\mathrm{CF}} 36, \mathrm{C} 2\right), 158.3,131.6$, 129.2, 113.8 (Ar), 117.0 (q, $J_{\mathrm{CF}} 281, \mathrm{C} 1$ ), 96.1 (q, $J_{\mathrm{CF}} 2$, C3), 55.2 (OMe), $40.5\left(\mathrm{CH}_{2}\right), 30.4\left(\mathrm{CH}_{2}\right) ;{ }^{19} \mathrm{~F}$ NMR $\left(376 \mathrm{MHz}, \mathrm{CDCl}_{3}\right) \delta-76.5\left(\mathrm{CF}_{3}\right)$; HRMS (ESI) $\mathrm{m} / z$, calcd. for $\mathrm{C}_{13} \mathrm{H}_{12} \mathrm{~F}_{3} \mathrm{O}_{3}[\mathrm{M}-1]^{-}: 273.0744$, found: 273.0806 .

\section{1,1,1-Trifluoro-5-(methylthio)hexan-2,4-dione (5k)}

Yield 90\%, yellow oil; IR (film) $v_{\max } / \mathrm{cm}^{-1} 3480,3415$, 3350, 3085, 2950, 2895, 2870, 1710, 1592, 1575, 1495, 1455, 1255, 1107, 1090; ${ }^{1} \mathrm{H}$ NMR $\left(400 \mathrm{MHz}, \mathrm{CDCl}_{3}\right) \delta 6.08$ (1H, s, H3), 3.31 (1H, q, J 7.2, H5), $1.98\left(3 \mathrm{H}, \mathrm{s}, \mathrm{SCH}_{3}\right)$, $1.39\left(3 \mathrm{H}, \mathrm{d}, J 7.2, \mathrm{CH}_{3}\right) ;{ }^{13} \mathrm{C} \mathrm{NMR}\left(100 \mathrm{MHz}, \mathrm{CDCl}_{3}\right)$ $\delta 198.6(\mathrm{C} 4), 178.1$ (q, $\left.J_{\mathrm{CF}} 36, \mathrm{C} 2\right), 117.6$ (q, $\left.J_{\mathrm{CF}} 280, \mathrm{C} 1\right)$, 95.6 (q, $\left.J_{\mathrm{CF}} 2.0, \mathrm{C} 3\right), 46.3$ (C5), 15.2 (C6), $12.9\left(\mathrm{SCH}_{3}\right)$; HRMS (ESI) $m / z$, calcd. for $\mathrm{C}_{7} \mathrm{H}_{8} \mathrm{~F}_{3} \mathrm{O}_{2} \mathrm{~S}[\mathrm{M}-1]^{-}: 213.0203$, found: 213.0258 .

3-(4-Oxo-2,6-bis(trifluoromethyl)-4H-pyran-3-yl) propanoic acid, a 4-pyranone derivative obtained from $3 \mathrm{n}$ (Scheme 6)

Yield 17\%, white needles; mp 118-120 ${ }^{\circ} \mathrm{C} ;{ }^{1} \mathrm{H}$ NMR $\left(400 \mathrm{MHz} \mathrm{CDCl}_{3}\right) \delta 2.60(\mathrm{~m}, \mathrm{H} 3,2 \mathrm{H}) ; 2.94(\mathrm{~m}, \mathrm{H} 2,2 \mathrm{H})$, 6.83 (s, 1H, H6); $\left.{ }^{13} \mathrm{C} \mathrm{NMR} \mathrm{(100} \mathrm{MHz,} \mathrm{CDCl}_{3}\right) \delta 177.4$ (q, ${ }^{4} J_{\mathrm{CF}} 2.0, \mathrm{C}^{\prime}$ ') $, 176.7(\mathrm{C} 1), 152.1$ (q, ${ }^{2} J_{\mathrm{CF}} 40, \mathrm{C} 2$ ') 149.4 (q, ${ }^{2} J_{\mathrm{CF}} 38, \mathrm{C}^{\prime}$ '), $129.4\left(\mathrm{C} 3\right.$ '), 118.8 (q, $\left.J_{\mathrm{CF}} 276, \mathrm{CF}_{3}\right), 117.7$ (q, $\left.J_{\mathrm{CF}} 274, \mathrm{CF}_{3}\right), 114.0\left(\mathrm{C}^{\prime}\right.$ '), $31.5(\mathrm{C} 2), 19.1\left(\mathrm{q},{ }^{4} J_{\mathrm{CF}} 2.0, \mathrm{C} 3\right)$.

\section{1,1,1-Trichloro-6-phenylhexan-2,4-dione (6h)}

Yield 89\%, brown oil; IR (film) $v_{\max } / \mathrm{cm}^{-1} 3510,3480$, 3450, 3090, 2940, 2910, 1690, 1595, 1560, 1495, 1465, 780, 750; ${ }^{1} \mathrm{H}$ NMR (400 MHz, $\left.\mathrm{CDCl}_{3}\right) \delta 7.29$ (2H, m, Ph), 7.20 (3H, m, Ph), 6.07 (1H, s, H3), 2.97 (2H, m, $\left.\mathrm{CH}_{2}\right)$, $2.91\left(2 \mathrm{H}, \mathrm{m}, \mathrm{CH}_{2}\right) ;{ }^{13} \mathrm{C}$ NMR $\left(100 \mathrm{MHz}, \mathrm{CDCl}_{3}\right) \delta 188.8$ (C4), 185.4 (C2), 139.6, 128.6, 128.2, $126.5(\mathrm{Ph}), 94.6$ (C1), 92.8 (C3), $38.4\left(\mathrm{CH}_{2}\right), 32.1\left(\mathrm{CH}_{2}\right)$; HRMS (ESI) $\mathrm{m} / \mathrm{z}$, calcd. for $\mathrm{C}_{12} \mathrm{H}_{12} \mathrm{Cl}_{3} \mathrm{O}_{2}\left[\mathrm{M}+\mathrm{H}^{+}:\right.$292.9903, 294.9873, found: 292.9968, 294.9930; anal. calcd. for $\mathrm{C}_{12} \mathrm{H}_{11} \mathrm{Cl}_{3} \mathrm{O}_{2}$ : C 49.09, H 3.78, found: C 49.45, H 3.80.

\section{1,1,1-Trichloro-5-(methylthio)hexan-2,4-dione (6k)}

Yield 95\%, yellow oil; IR (film) $v_{\max } / \mathrm{cm}^{-1} 3510,3480$, 2940, 2910, 2870, 1710, 1690, 1680, 1592, 1575, 1495, 1455, 780, 750; ${ }^{1} \mathrm{H}$ NMR (400 MHz, $\left.\mathrm{CDCl}_{3}\right) \delta 6.28(1 \mathrm{H}, \mathrm{s}$, 
H3 enol), 4.35 (q, 2H, J 7.0, H3 keto), 3.51 (1H, q, J 7.0, H5, keto), 3.38 (1H, q, J 7.0, H5 enol) 2.14 (3H, s, $\mathrm{SCH}_{3}$ enol), 1.95 ( $3 \mathrm{H}, \mathrm{s}, \mathrm{SCH}_{3}$ keto), 1.51 (3H, d, J 7.0, $\mathrm{CH}_{3}$ enol), 1.43 (3H, d, J 7.0, $\mathrm{CH}_{3}$ keto); ${ }^{13} \mathrm{C} \mathrm{NMR}\left(100 \mathrm{MHz}, \mathrm{CDCl}_{3}\right) \delta$ enol 189.7 (C4), 184.5 (C2), 94.3 (C1), 91.5 (C3), 44.9 (C5), 16.7 (C6), $14.2\left(\mathrm{SCH}_{3}\right) ; \delta$ keto $194.5(\mathrm{C} 4), 186.1(\mathrm{C} 2), 95.8$ (C1), 47.8 (C3), 46.9 (C5), 16.5 (C6), 13.5 ( $\left.\mathrm{SCH}_{3}\right)$; HRMS (ESI) $\mathrm{m} / z$, calcd. for $\mathrm{C}_{7} \mathrm{H}_{10} \mathrm{Cl}_{3} \mathrm{O}_{2} \mathrm{~S}[\mathrm{M}+\mathrm{H}]^{+}:$262.9467, 264.9438, found: 262.9528, 264.9492; anal. calcd. for $\mathrm{C}_{7} \mathrm{H}_{9} \mathrm{Cl}_{3} \mathrm{O}_{2} \mathrm{~S}$ : C 31.90, H 3.44, found: C 31.79, H 3.58.

\section{5-Trihalomethyl-4,5-dihydroisoxazoles $(\mathbf{8 , 9})$}

\section{General procedure}

Trifluoromethyl-substituted precursors $\mathbf{3 h}, \mathbf{k}, \mathbf{l}, \mathbf{n}$ or $\mathbf{5 h}, \mathbf{k}(6.0 \mathrm{mmol})$ or trichloromethyl-substituted precursors $\mathbf{4 a - c}, \mathbf{4 f}-\mathbf{h}, \mathbf{4 k}, \mathbf{n}$, or $\mathbf{6 h}, \mathbf{k}(6.0 \mathrm{mmol})$ and hydroxylamine hydrochloride $(6.1 \mathrm{mmol}, 0.45 \mathrm{~g})$ were efficiently stirred in $5 \mathrm{~mL}$ ethanol, under slight heating, $40-45{ }^{\circ} \mathrm{C}$, for 30-120 min. Then solvent was evaporated and solid residue was assigned as 4,5-dihydroisoxazole derivatives $\mathbf{8 h}, \mathbf{k}, \mathbf{l}, \mathbf{n}$ and $\mathbf{9 a - c}, \mathbf{9 f}-\mathbf{h}$, and $\mathbf{9 k}, \mathbf{n}$ in good to quantitative yields.

5-Hydroxy-5-trifluoromethyl-3-(2-phenylethyl)4,5-dihydroisoxazole (8h)

Yield 95\%, white solid; mp 87-88 ${ }^{\circ} \mathrm{C} ;{ }^{1} \mathrm{H}$ NMR (400 MHz, $\left.\mathrm{CDCl}_{3}\right) \delta 7.34$ (2H, m, Ph), 7.25 (m, 3H, Ph), $3.25\left(1 \mathrm{H}, \mathrm{d}, J_{\mathrm{HH}} 18, \mathrm{H} 4\right), 3.01\left(1 \mathrm{H}, \mathrm{d}, J_{\mathrm{HH}} 18, \mathrm{H} 4\right), 2.96$ $\left(\mathrm{t}, 2 \mathrm{H}, J_{\mathrm{HH}} 8.0, \mathrm{CH}_{2}\right), 2.74\left(\mathrm{t}, 2 \mathrm{H}, J_{\mathrm{HH}} 8.0, \mathrm{CH}_{2}\right) ;{ }^{13} \mathrm{C} \mathrm{NMR}$ $\left(100 \mathrm{MHz}, \mathrm{CDCl}_{3}\right) \delta 158.9$ (C3), 139.8, 128.7, 128.2, 126.6 $(\mathrm{Ph}), 122.0\left(\mathrm{q}, J_{\mathrm{CF}} 284, \mathrm{CF}_{3}\right), 102.6\left(\mathrm{q}, J_{\mathrm{CF}} 34, \mathrm{C} 5\right), 45.2$ (C4), 32.4, $\left(\mathrm{CH}_{2}\right), 29.1\left(\mathrm{CH}_{2}\right)$; HRMS (ESI) $\mathrm{m} / \mathrm{z}$, calcd. for $\mathrm{C}_{12} \mathrm{H}_{13} \mathrm{~F}_{3} \mathrm{NO}_{2}[\mathrm{M}+\mathrm{H}]^{+}:$260.0898, found: 260.0956; anal. calcd. for $\mathrm{C}_{12} \mathrm{H}_{12} \mathrm{~F}_{3} \mathrm{NO}_{2}$ : C 55.60, $\mathrm{H} 4.67$, found: C 55.50, H 4.78.

5-Hydroxy-5-trifluoromethyl-3-(1-(thiomethyl)ethyl)-4,5dihydroisoxazole (8k)

Yield 93\%, white needles; mp 70-75 ${ }^{\circ} \mathrm{C} ;{ }^{1} \mathrm{H}$ NMR $\left(400 \mathrm{MHz}, \mathrm{CDCl}_{3}\right) \delta 3.72$ (q, 1H, $\left.J_{\mathrm{HH}} 7.2, \mathrm{CH}\right), 3.54$ (d, $\left.1 \mathrm{H}, J_{\mathrm{HH}} 18, \mathrm{H} 4\right), 3.44$ (d, 1H, $\left.J_{\mathrm{HH}} 18, \mathrm{H} 4\right), 3.29(\mathrm{~d}, 1 \mathrm{H}$, $\left.J_{\mathrm{HH}} 18, \mathrm{H} 4\right), 3.21\left(\mathrm{~d}, 1 \mathrm{H}, J_{\mathrm{HH}} 18, \mathrm{H} 4\right), 2.05$ (s, 3H, $\left.\mathrm{CH}_{3}\right)$, $2.03\left(\mathrm{~s}, 3 \mathrm{H}, \mathrm{CH}_{3}\right), 1.49\left(\mathrm{~d}, 3 \mathrm{H}, J_{\mathrm{HH}} 7.2, \mathrm{CH}_{3}\right), 1.48(\mathrm{~d}$, $\left.3 \mathrm{H}, J_{\mathrm{HH}} 7.2, \mathrm{CH}_{3}\right) ;{ }^{13} \mathrm{C} \mathrm{NMR}\left(100 \mathrm{MHz}, \mathrm{CDCl}_{3}\right) \delta 160.7$, 160.6 (C3), 121.9 (q, $J_{\mathrm{HH}} 282, \mathrm{CF}_{3}$ ), 41.4, 41.1 (C4), 37.6, $37.4(\mathrm{CH}), 17.6,17.2\left(\mathrm{CH}_{3}\right), 13.6,13.3\left(\mathrm{CH}_{3}\right) ;{ }^{19} \mathrm{~F}$ NMR (376 $\mathrm{MHz}, \mathrm{CDCl}_{3}$ ) $\delta-82.6,-83.0$; HRMS (ESI) $\mathrm{m} / \mathrm{z}$, calcd. for $\mathrm{C}_{7} \mathrm{H}_{11} \mathrm{~F}_{3} \mathrm{NO}_{2} \mathrm{~S}[\mathrm{M}+\mathrm{H}]^{+}$: 230.0463, found: 230.0511; anal. calcd. for $\mathrm{C}_{7} \mathrm{H}_{10} \mathrm{~F}_{3} \mathrm{NO}_{2} \mathrm{~S}$ : C 36.68, $\mathrm{H} 4.40$, found: C $36.50, \mathrm{H} 4.45$.
5-Hydroxy-3-(2-methoxybenzyl)-5-trifluoromethyl4,5-dihydroisoxazole (8I)

Yield 91\%, white needles; mp 131-132 ${ }^{\circ} \mathrm{C} ;{ }^{1} \mathrm{H}$ NMR $\left(400 \mathrm{MHz}, \mathrm{CDCl}_{3}\right) \delta 7.31\left(\mathrm{dd}, 1 \mathrm{H}, J_{\mathrm{HH}} 8.0,1.6, \mathrm{Ar}\right), 7.19$ $\left(\mathrm{dd}, 1 \mathrm{H}, J_{\mathrm{HH}} 7.6,1.6, \mathrm{Ar}\right), 6.95\left(\mathrm{td}, 1 \mathrm{H}, J_{\mathrm{HH}} 7.5,1.0, \mathrm{Ar}\right)$, $6.92\left(\mathrm{~d}, 1 \mathrm{H}, J_{\mathrm{HH}} 8.0, \mathrm{Ar}\right), 3.86\left(\mathrm{~s}, 3 \mathrm{H}, \mathrm{OCH}_{3}\right), 3.77(\mathrm{~s}, 2 \mathrm{H}$, $\mathrm{CH}_{2}$ ), 3.22 (d, 1H, $\left.J_{\mathrm{HH}} 18, \mathrm{H} 4\right), 3.01$ (d, 1H, $\left.J_{\mathrm{HH}} 18, \mathrm{H} 4\right)$; ${ }^{13} \mathrm{C} \mathrm{NMR}\left(100 \mathrm{MHz}, \mathrm{CDCl}_{3}\right) \delta 159.1$ (Ar), 157.2 (C3); 130.5 (Ar); 128.9 (Ar) 123.0 (Ar), 122.0 (q, $J_{\mathrm{HH}} 284$, $\mathrm{CF}_{3}$ ), 121.0 (Ar), 110.0 (Ar), 102.6 (q, $\left.J_{\mathrm{HH}} 34, \mathrm{C} 5\right), 55.3$ $\left(\mathrm{OCH}_{3}\right), 44.6(\mathrm{C} 4), 27.9\left(\mathrm{CH}_{2}\right)$; HRMS (ESI) $\mathrm{m} / \mathrm{z}$, calcd. for $\mathrm{C}_{12} \mathrm{H}_{13} \mathrm{~F}_{3} \mathrm{NO}_{3}[\mathrm{M}+\mathrm{H}]^{+}:$276.0848, found: 276.0883; anal. calcd. for $\mathrm{C}_{12} \mathrm{H}_{12} \mathrm{~F}_{3} \mathrm{NO}_{3}$ : C 52.37, $\mathrm{H} 4.39$, found: C 52.50, H 4.35.

The data for isoxazole derivative $\mathbf{8 m}$ obtained in this work are precisely in agreement with those previously described by Flores et al. ${ }^{41}$

5-Trichloromethyl-3-heptyl-4,5-dihydroisoxazole (9a)

Yield 90\%, white needles; mp 83-84 ${ }^{\circ} \mathrm{C}$; ${ }^{1} \mathrm{H}$ NMR $\left(400 \mathrm{MHz}, \mathrm{CDCl}_{3}\right) \delta 0.81\left(\mathrm{t}, 3 \mathrm{H}, \mathrm{CH}_{3}\right), 1.25(\mathrm{~m}, 8 \mathrm{H}$, $\left.-\mathrm{CH}_{2}-\right), 1.51\left(\mathrm{~m}, 2 \mathrm{H}, \beta-\mathrm{CH}_{2}\right), 2.32\left(\mathrm{t}, 2 \mathrm{H}, J\right.$ 7.6, $\left.\alpha-\mathrm{CH}_{2}\right)$, 3.12 (d, 1H, J 18.4, H-4), 3.55 (d, 1H, J 18.4, H-4); ${ }^{13} \mathrm{C} \mathrm{NMR}\left(100 \mathrm{MHz}, \mathrm{CDCl}_{3}\right) \delta 160.6$ (C3), 46.1 (C4), 110.5 (C5), $101.1\left(\mathrm{CCl}_{3}\right), 31.2,28.6 .27 .5,26.1,22.3\left(-\mathrm{CH}_{2}-\right)$, $13.9\left(\mathrm{CH}_{3}\right)$; Fourier transform MS (FTMS) calcd. for $\mathrm{C}_{10} \mathrm{H}_{16} \mathrm{Cl}_{3} \mathrm{NO}_{2}: 287.0247 \mathrm{~g} \mathrm{~mol}^{-1}$; found: $288.0307 \mathrm{~g} \mathrm{~mol}^{-1}$.

The NMR spectroscopic data for the complete series of the 3-alkyl-5-hydroxy-5-trichloromethyl4,5-dihydroisoxazoles $\mathbf{9 b - f}$ are shown in the SI section.

5-Hydroxy-3-(4-methylpent-3-en-1-yl)-5-trichloromethyl4,5-dihydroisoxazol (9g)

Yield 91\%, white needles; mp 118-119 ${ }^{\circ} \mathrm{C} ;{ }^{1} \mathrm{H}$ NMR (400 MHz, $\left.\mathrm{CDCl}_{3}\right) \delta 1.63$ (s, 3H, $\mathrm{CH}_{3}$ ), 1.70 (s, 3H, $\mathrm{CH}_{3}$ ), $2.30\left(\mathrm{~m}, 2 \mathrm{H}, \mathrm{CH}_{2}\right), 2.45\left(\mathrm{~m}, 2 \mathrm{H}, \mathrm{CH}_{2}\right), 3.17$ (d, 1H, $J_{\mathrm{HH}} 18.4$, H4), 3.61 (d, 1H, $\left.J_{\mathrm{HH}} 18.4, \mathrm{H} 4\right), 5,11\left(\mathrm{tt}, 1 \mathrm{H}, J_{\mathrm{HH}} 7.2,1.6\right.$, $\mathrm{CH}) ;{ }^{13} \mathrm{C} \mathrm{NMR}\left(100 \mathrm{MHz}, \mathrm{CDCl}_{3}\right) \delta 160.1$ (C3), 133.6 $\left(\left(\mathrm{CH}_{3}\right)_{2}\right) ; 122.0(\mathrm{CH}) ; 110.4(\mathrm{C} 5) 101.1,\left(\mathrm{CCl}_{3}\right) ; 46.1(\mathrm{C} 4)$, $27.7\left(\mathrm{CH}_{2}\right), 25.5\left(\mathrm{CH}_{3}\right), 24.9\left(\mathrm{CH}_{2}\right), 17.7\left(\mathrm{CH}_{3}\right)$; MS (EI, $70 \mathrm{eV}) \mathrm{m} / \mathrm{z}(\%) 289\left(\mathrm{M}^{+}+4,9\right), 287\left(\mathrm{M}^{+}+2,26\right), 285\left(\mathrm{M}^{+}\right.$, 30), 206 (62), 178 (21), 143 (23), 117 (28); anal. calcd. for $\mathrm{C}_{10} \mathrm{H}_{14} \mathrm{Cl}_{3} \mathrm{NO}_{2}\left(286.58 \mathrm{~g} \mathrm{~mol}^{-1}\right.$ ): $\mathrm{C} 41.91, \mathrm{H} 4.92, \mathrm{~N} 4.89$, found: C 41.9, H 4.85, N 4.9.

5-Hydroxy-5-trichloromethyl-3-(2-phenylethyl)4,5-dihydroisoxazole (9h)

Yield 93\%, white solid; mp 131-132 ${ }^{\circ} \mathrm{C}$; ${ }^{1} \mathrm{H}$ NMR (400 MHz, $\left.\mathrm{CDCl}_{3}\right) \delta 7.30$ (2H, m, Ph), 7.24 (m, 3H, Ph), $3.55\left(1 \mathrm{H}, \mathrm{d}, J_{\mathrm{HH}} 18.4, \mathrm{H} 4\right), 3.13\left(1 \mathrm{H}, \mathrm{d}, J_{\mathrm{HH}} 18.4, \mathrm{H} 4\right)$, $2.95\left(\mathrm{t}, 2 \mathrm{H}, J_{\mathrm{HH}} 8.0, \mathrm{CH}_{2}\right), 2.74\left(\mathrm{~m}, 2 \mathrm{H}, \mathrm{CH}_{2}\right) ;{ }^{13} \mathrm{C} \mathrm{NMR}$ 
$\left(100 \mathrm{MHz}, \mathrm{CDCl}_{3}\right) \delta 159.6(\mathrm{C} 3), 139.8,128.6,128.2,126.5$ (Ph), 110.5 (C5), $100.9\left(\mathrm{CCl}_{3}\right), 46.1(\mathrm{C} 4), 32.4,\left(\mathrm{CH}_{2}\right), 29.3$ $\left(\mathrm{CH}_{2}\right)$; HRMS (ESI) $\mathrm{m} / z$, calcd. for $\mathrm{C}_{12} \mathrm{H}_{13} \mathrm{Cl}_{3} \mathrm{NO}_{2}[\mathrm{M}+\mathrm{H}]^{+}$: 260.0898, found: 308.0074, 310.0027; anal. calcd. for $\mathrm{C}_{12} \mathrm{H}_{12} \mathrm{Cl}_{3} \mathrm{NO}_{2}$ : C 46.71, H 3.92, found: C 46.89, H 3.80.

5-Hydroxy-5-trifluoromethyl-3-(1-(thiomethyl)ethyl)4,5-dihydroisoxazole (9k)

Yield 88\%, white needles; mp 70-75 ${ }^{\circ} \mathrm{C}$; ${ }^{1} \mathrm{H}$ NMR $\left(400 \mathrm{MHz}, \mathrm{CDCl}_{3}\right) \delta 3.85\left(\mathrm{~d}, 1 \mathrm{H}, J_{\mathrm{HH}} 18, \mathrm{H} 4\right), 3.76(\mathrm{~d}, 1 \mathrm{H}$, $\left.J_{\mathrm{HH}} 18.4, \mathrm{H} 4\right), 3.68\left(\mathrm{q}, 1 \mathrm{H}, J_{\mathrm{HH}} 7.4, \mathrm{CH}\right), 3.37\left(\mathrm{~d}, 1 \mathrm{H}, J_{\mathrm{HH}} 18\right.$, $\mathrm{H} 4), 3.29\left(\mathrm{~d}, 1 \mathrm{H}, J_{\mathrm{HH}} 18.4, \mathrm{H} 4\right), 2.05\left(\mathrm{~s}, 6 \mathrm{H}, 2 \times \mathrm{CH}_{3}\right), 1.48$ $\left(\mathrm{d}, 3 \mathrm{H}, \mathrm{J}_{\mathrm{HH}} 7.2, \mathrm{CH}_{3}\right) ;{ }^{13} \mathrm{CNMR}\left(100 \mathrm{MHz}, \mathrm{CDCl}_{3}\right) \delta 161.05$, 161.03 (C3), 110.6 (C5), 100.9, 100.8 ( $\left.\mathrm{CCl}_{3}\right), 42.6,42.1$ (C4), 38.0, $37.7(\mathrm{CH}), 17.7,17.3\left(\mathrm{CH}_{3}\right), 14.0,13.2\left(\mathrm{CH}_{3}\right)$; HRMS (ESI) $\mathrm{m} / z$, calcd. for $\mathrm{C}_{7} \mathrm{H}_{11} \mathrm{Cl}_{3} \mathrm{NO}_{2} \mathrm{~S}[\mathrm{M}+\mathrm{H}]^{+}: 276.9498$, 278.9468, found: 276.9541, 278.9522; anal. calcd. for $\mathrm{C}_{7} \mathrm{H}_{10} \mathrm{Cl}_{3} \mathrm{NO}_{2} \mathrm{~S}$ : C 30.18, H 3.62, found: C 30.20, H 3.70.

\section{5-Trichloromethylisoxazoles}

Compounds 9a-c and $\mathbf{9 e}, \mathbf{f}(3.5 \mathrm{mmol})$ were efficiently stirred with $98 \% \mathrm{H}_{2} \mathrm{SO}_{4}(2.0 \mathrm{~mL})$ for $5 \mathrm{~h}$. Then cooled water was added and the insoluble residue was filtered and washed with water and a saturated solution of $\mathrm{NaHCO}_{3}$, producing 5-trichloromethylisoxazole derivatives 11a-c, and $\mathbf{9 e , f}$ in good yields (Table 1).

\section{5-Trichloromethyl-3-undecylisoxazole (11e)}

Yield 90\%, yellow oil; ${ }^{1} \mathrm{H}$ NMR (400 $\mathrm{MHz}, \mathrm{CDCl}_{3}$ ) $\delta 0.98$ (t, 3H, J 7.8, Me), 1.75 (sx, 2H, J 7.8, $-\mathrm{CH}_{2}-$ ), 2.7 (t, $\left.2 \mathrm{H}, J 7.8,-\mathrm{CH}_{2}-\right), 6.88$ (s, $\left.1 \mathrm{H}, \mathrm{H} 4\right) ;{ }^{13} \mathrm{C} \mathrm{NMR}(50 \mathrm{MHz}$, $\left.\mathrm{CDCl}_{3}\right) \delta 165.3(\mathrm{C} 3), 104.7(\mathrm{C} 4), 168.7$ (C5), $85.6\left(\mathrm{CCl}_{3}\right)$, $28.3\left(-\mathrm{CH}_{2}-\right), 21.8\left(-\mathrm{CH}_{2}-\right), 13.8(\mathrm{Me})$; HRMS (ESI) $\mathrm{m} / \mathrm{z}$, calcd. for $\mathrm{C}_{15} \mathrm{H}_{24} \mathrm{Cl}_{3} \mathrm{NO}[\mathrm{M}+\mathrm{H}]^{+}:$340.1002, 342.0972, found: 340.0986, 342.0957.

Complete identification data for all isolated 5-trichloromethylisoxazoles are available in the SI section.

\section{$1 H$-Pyrazole derivatives}

\section{Trifluoromethyl-1 $H$-pyrazoles}

A solution of hydrazine hydrochloride $(21 \mathrm{mmol})$ and 6-aryl-1,1,1-trifluoro-4-methoxyhex-3-en-2-one ( $\mathbf{3 h}$ or $\mathbf{3 j}$, $20 \mathrm{mmol})$ in ethanol $(10 \mathrm{~mL})$ was stirred at reflux for $12 \mathrm{~h}$. Ethanol was evaporated and a brownish solid residue was recrystallized from hexane, obtaining $1 H$-pyrazole products $\mathbf{1 2 h}, \mathbf{j}$ in very good yields (> 80\%).

5(3)-Trifluoromethyl-3(5)-(2-phenylethyl)-1 H-pyrazole (12h) Yield $88 \%$, yellowish oil; ${ }^{1} \mathrm{H}$ NMR $\left(400 \mathrm{MHz}, \mathrm{CDCl}_{3}\right)$ $\delta$ 7.32-7.15 (5H, m, Ph), $6.32(1 \mathrm{H}, \mathrm{s}, \mathrm{H} 4), 3.01\left(2 \mathrm{H}, \mathrm{m}, \mathrm{CH}_{2}\right)$, $2.96\left(2 \mathrm{H}, \mathrm{m}, \mathrm{CH}_{2}\right) ;{ }^{13} \mathrm{C} \mathrm{NMR}\left(100 \mathrm{MHz}, \mathrm{CDCl}_{3}\right) \delta 144.7$ (C3), 143.0 (q, $\left.J_{\mathrm{CF}} 38, \mathrm{C} 5\right) 139.9,128.7,128.3,126.6(\mathrm{Ph})$, $121.3\left(\mathrm{q}, J_{\mathrm{CF}} 268, \mathrm{C} 5\right), 102.2\left(\mathrm{q}, J_{\mathrm{CF}} 1.5, \mathrm{C} 4\right), 35.0\left(\mathrm{CH}_{2}\right), 27.1$ $\left(\mathrm{CH}_{2}\right)$; HRMS (ESI) $\mathrm{m} / z$, calcd. for $\mathrm{C}_{12} \mathrm{H}_{12} \mathrm{~F}_{3} \mathrm{~N}_{2}[\mathrm{M}+\mathrm{H}]^{+}$: 241.0953, found: 241.0965; anal. calcd. for $\mathrm{C}_{12} \mathrm{H}_{12} \mathrm{~F}_{3} \mathrm{~N}_{2}$ : C 60.00, H 4.62, found: C 59.95, H 4.60.

5(3)-Trifluoromethyl-3(5)-(2-(4-methoxyphenyl)ethyl)$1 \mathrm{H}$-pyrazole (12j)

Yield 85\%, yellowish oil; ${ }^{1} \mathrm{H}$ NMR $\left(400 \mathrm{MHz}, \mathrm{CDCl}_{3}\right)$ $\delta 7.09\left(2 \mathrm{H}, \mathrm{d}, J_{\mathrm{HH}} 8.0, \mathrm{Ar}\right), 6.85\left(2 \mathrm{H}, \mathrm{d}, J_{\mathrm{HH}} 8.0, \mathrm{Ar}\right)$, $6.34(1 \mathrm{H}, \mathrm{s}, \mathrm{H} 4), 3.81\left(3 \mathrm{H}, \mathrm{s}, \mathrm{OCH}_{3}\right), 3.0\left(2 \mathrm{H}, \mathrm{m}, \mathrm{CH}_{2}\right)$, $2.93\left(2 \mathrm{H}, \mathrm{m}, \mathrm{CH}_{2}\right) ;{ }^{13} \mathrm{C}$ NMR $\left(100 \mathrm{MHz}, \mathrm{CDCl}_{3}\right) \delta 158.3$ (Ar), 145.4 (C3), 142.4 (q, $\left.J_{\mathrm{CF}} 38, \mathrm{C} 5\right)$ 131.9, 129.2 (Ar), 121.1(q, $\left.J_{\mathrm{CF}} 268, \mathrm{C} 5\right), 114.0(\mathrm{Ar}), 102.4$ (q, $\left.J_{\mathrm{CF}} 1.8, \mathrm{C} 4\right)$, $55.2\left(\mathrm{OCH}_{3}\right), 34.1,\left(\mathrm{CH}_{2}\right), 27.4\left(\mathrm{CH}_{2}\right) ;{ }^{19} \mathrm{~F} \mathrm{NMR}(376 \mathrm{MHz}$, $\mathrm{CDCl}_{3}$ ) $\delta-62.07$; HRMS (ESI) $m / z$, calcd. for $\mathrm{C}_{13} \mathrm{H}_{14} \mathrm{~F}_{3} \mathrm{~N}_{2} \mathrm{O}$ $[\mathrm{M}+\mathrm{H}]^{+}:$:271.1058, found: 271.1118; anal. calcd. for $\mathrm{C}_{13} \mathrm{H}_{13} \mathrm{~F}_{3} \mathrm{~N}_{2} \mathrm{O}$ : C 57.78, H 4.85, found: C 57.65, H 4.80 .

\section{H-Pyrazole-5-carboxylates}

A mixture of precursors $4 \mathrm{~h}$ or $6 \mathbf{h}(10 \mathrm{mmol})$ and $\mathrm{NH}_{2} \mathrm{NH}_{2} \mathrm{HCl}(11 \mathrm{mmol}, 0.76 \mathrm{~g})$ in $5 \mathrm{~mL}$ alcohol (EtOH or 2-methoxyethanol (2ME)) was stirred under reflux for $8 \mathrm{~h}$. The solvent was evaporated, the solid residue was dissolved in $\mathrm{CH}_{2} \mathrm{Cl}_{2}(20 \mathrm{~mL})$ and washed with water $(15 \mathrm{~mL})$ twice, and then the organic layer was dried with $\mathrm{Na}_{2} \mathrm{SO}_{4}$. After evaporating the solvent, the residues were obtained as white solids, attributed as $1 \mathrm{H}$-pyrazole carboxylates $\mathbf{1 3 h}$ and $\mathbf{1 4 h}$. Here we use these models to demonstrate the versatility of trichloromethyl-substituted precursors in molecular diversification during the synthesis of $1 H$-pyrazole carboxylates:

Ethyl 3(5)-(2-phenylethyl)-1H-pyrazole-5(3)-carboxylate (13h)

Yield 90\%, white solid; mp $216{ }^{\circ} \mathrm{C} ;{ }^{1} \mathrm{H}$ NMR $(400 \mathrm{MHz}$, $\left.\mathrm{CDCl}_{3}\right) \delta$ 7.23-7.12 (5H, m, Ph), $6.64(1 \mathrm{H}, \mathrm{s}, \mathrm{H} 4), 4.35(2 \mathrm{H}$, q, $\left.J_{\mathrm{HH}} 6.8, \mathrm{CH}_{2}\right), 3.15\left(2 \mathrm{H}, \mathrm{m}, \mathrm{CH}_{2}\right), 3.00\left(2 \mathrm{H}, \mathrm{m}, \mathrm{CH}_{2}\right)$, $1.33\left(3 \mathrm{H}, \mathrm{t}, J_{\mathrm{HH}} 6.8, \mathrm{CH}_{3}\right) ;{ }^{13} \mathrm{C} \mathrm{NMR}\left(100 \mathrm{MHz}, \mathrm{CDCl}_{3}\right) \delta$ $157.0\left(\mathrm{CO}_{2} \mathrm{Et}\right), 149.5(\mathrm{C} 3), 138.9(\mathrm{Ph}), 137.8(\mathrm{C} 5), 128.3$, 128.1, $126.3(\mathrm{Ph}), 108.1(\mathrm{C} 4), 62.6\left(\mathrm{OCH}_{2}\right), 33.8\left(\mathrm{CH}_{2}\right)$, $26.8\left(\mathrm{CH}_{2}\right), 13.6\left(\mathrm{CH}_{3}\right) ; \mathrm{MS}(70 \mathrm{eV}) \mathrm{m} / z(\%) 211\left(\mathrm{M}^{+}+1\right.$, 10), $210\left(\mathrm{M}^{+}, 60\right)$; anal. calcd. for $\mathrm{C}_{11} \mathrm{H}_{18} \mathrm{~N}_{2} \mathrm{O}_{2}: \mathrm{C} 62.83, \mathrm{H}$ 8.63, found: C 62.7, H 8.7.

2-Methoxyethyl 3(5)-(2-phenylethyl)-1H-pyrazole5(3)-carboxylate (14h)

Yield 93\%, white solid; mp 130-131 ${ }^{\circ} \mathrm{C}$; ${ }^{1} \mathrm{H}$ NMR (400 MHz, $\mathrm{CDCl}_{3}$ ) $\delta 6.49$ (s, 1H, H4), 3.77 (s, 3H, OMe), 
2.61 (t, 2H, H6), 1.52 (qu, 2H, H7), $1.18\left(\mathrm{~m}, 8 \mathrm{H},-\left(\mathrm{CH}_{2}\right)_{4}-\right)$, 0.77 (t, 3H, Me); ${ }^{13} \mathrm{C}$ NMR (100 MHz, $\left.\mathrm{CDCl}_{3}\right) \delta 162.3$ $\left(\mathrm{CO}_{2} \mathrm{Me}\right), 147.3(\mathrm{C} 3), 141.4(\mathrm{C} 5), 106.1(\mathrm{C} 4), 51.7(\mathrm{OMe})$, 31.6, 28.97, 28.93, 28.8, 25.6, $22.5\left(\mathrm{CH}_{2}\right), 13.9(\mathrm{Me})$; $\mathrm{MS}$ $(70 \mathrm{eV}) \mathrm{m} / \mathrm{z}(\%) 225\left(\mathrm{M}^{+}+1,10\right), 224\left(\mathrm{M}^{+}, 58\right)$; anal. calcd. for $\mathrm{C}_{12} \mathrm{H}_{20} \mathrm{~N}_{2} \mathrm{O}_{2}$ : C 64.26, $\mathrm{H}$ 8.99, found: C 64.5, H 8.9.

\section{Supplementary Information}

Supplementary information $\left({ }^{1} \mathrm{H},{ }^{13} \mathrm{C}\right.$ and representative ${ }^{19} \mathrm{~F}$ NMR spectra, and MS of the synthesized compounds) is available free of charge at http://jbcs.sbq.org.br as PDF file.

\section{Acknowledgments}

Financial support from Conselho Nacional de Desenvolvimento Científico e Tecnológico (CNPq) and Fundação de Amparo à Pesquisa do Estado do Rio Grande do Sul (FAPERGS) is acknowledged. V. D. O. Bareño, D. S. Santos, and D. L. de Mello thank CAPES for fellowships.

\section{References}

1. Druzhinin, S. V.; Balenkova, E. S.; Nenajdenko, V. G.; Tetrahedron 2007, 63, 7753.

2. Rulev, A. Yu.; Romanov, A. R.; RSC Adv. 2016, 6, 1984.

3. Martins, M. A. P.; Cunico, W.; Pereira, C. M. P.; Sinhorin, A. P.; Flores, A. F. C.; Bonacorso, H. G.; Zanatta, N.; Curr. Org. Synth. 2004, 1, 391.

4. Nenajdenko, V. G.; Balenkova, E. S.; ARKIVOC 2011, 2011, 246.

5. Olivier, J-.H.; Camerel, F.; Ziessel, R.; Chem. - Eur. J. 2011, 17, 9113.

6. Sloop, J. C.; Bumgardner, C. L. Washington, G.; Loehle, W. D.; Sankar, S. S.; Lewis, A. B.; J. Fluorine Chem. 2006, 127, 780.

7. Yang, Y.; Zhang, M.; Zhu, Y.; Zhang, L.; Xie, Q.; Song, L.; Deng, H.; Chin. J. Chem. 2013, 31, 950.

8. Bhakite, E. A.; Abdel-Rahman, A. E.; Al-Taifi, E. A.; Arabian J. Chem. 2014, 7, 936.

9. Chauvin, A-.S.; Gumy, F.; Matsubayashi, I.; Hasegawa, H.; Bünzli, J-.C. G.; Eur. J. Inorg. Chem. 2006, 473.

10. Pace, A.; Buscemi, S.; Vivona, N.; Org. Prep. Proced. Int. 2007, $39,1$.

11. Kudyakova, Yu. S.; Bazhin, D. N.; Goryaeva, M. V.; Burgart, Ya. V.; Saloutin, V. I.; Russ. Chem. Rev. 2014, 83, 120.

12. DelaRosa, M. J.; Banger, K. K.; Higashiya, S.; Ngo, S. C.; Hunt, D. H.; Bousman, K. S.; Toscano, P. J.; Welch, J. T.; J. Fluorine Chem. 2003, 123, 109.

13. Khamidullina, L. A.; Obydennov, K. L.; Slepukhin, P. A.; Puzyrev, I. S.; J. Mol. Struct. 2016, 1125, 550.
14. Nakamura, K.; Hasegawa, Y.; Kawai, H.; Yasuda, N.; Kanehisa, N.; Kai, Y.; Nagamura, T.; Yanagida, S.; Wada, Y.; J. Phys. Chem. A 2007, 111, 3029.

15. Rogachev, A. Yu.; Mironov, A. V.; Nemukhin, A. V.; J. Mol. Struct. 2007, 831, 46.

16. Xiang, N-.J.; Leung, L. M.; So, S-.K.; Gong, M-.L.; Spectrochim. Acta, Part A 2006, 65, 907.

17. Bazhin, D. N.; Kudyakova, Y. S.; Bogomyakov, A. S.; Slepukhin, P. A.; Kim, G. A.; Burgart, Y. V.; Saloutin, V. I.; Inorg. Chem. Front. 2019, 6, 40.

18. Turgambaeva, A. E.; Krisyuk, V. V.; Baidina, I. A.; Korolkov, I. V.; Ilyin, I. Yu.; Urkasym kyzy, S.; Igumenov, I. K.; J. Struct. Chem. 2017, 58, 1530.

19. Zharkova, G. I.; Baidina, I. A.; Turgambaeva, A. E.; Romanenko, G. V.; Igumenov, I. K.; Polyhedron 2012, 40, 40.

20. Krisyuk, V. V.; Kyzy, S. U.; Rybalova, T. V.; Baidina, I. A.; Korolkov, D. L.; Chizhov, D. L.; Bazhin, D. N.; Kudyakova, Y. S.; J. Coord. Chem. 2018, 71, 2194.

21. Fustero, S.; Sánchez-Roselló, M.; Barrio, P.; Simón-Fuentes, A.; Chem. Rev. 2011, 111, 6984.

22. Kumar, V.; Kaur, K.; J. Fluorine Chem. 2015, 180, 55.

23. Emelina, E. E.; Petrov, A. A.; Stanislav, I. S.; Nelyubina, Y. V.; Antipin, M. Yu.; J. Fluorine Chem. 2009, 130, 861.

24. Tireli, M.; Maracic, S.; Lukin, S.; Kulcsár, M. J.; Zilic, D.; Cetina, M.; Halasz, I.; Malic, S.; Uzarevic, K.; Beilstein J. Org. Chem. 2017, 13, 2352.

25. Bazhin, D. N.; Chizhov, D. L.; Röschenthaler, G-.V.; Kudyakova, Y. S.; Burgart, Y. V.; Slepukhin, P. A.; Saloutin, V. I.; Charushin, V. N.; Tetrahedron Lett. 2014, 55, 5714.

26. Grünebaum, M.; Buchheit, A.; Gunther, C.; Wiemhöfer, H-.D.; Tetrahedron Lett. 2016, 57, 1555.

27. Safrygin, A. V.; Irgashev, R. A.; Slepukhin, P. A.; Röschenthaler, G-.V.; Sosnovskikh, V. Y.; Tetrahedron 2015, 71, 8535.

28. Irgashev, R. A.; Sosnovskikh, V. Ya.; Kalinovich, N.; Kazakova, O.; Röschenthaler G-.V.; Tetrahedron Lett. 2009, 50, 4903.

29. Kende, A. S.; Blacklock, T. J.; Tetrahedron Lett. 1980, $21,3119$.

30. Mander, L.; Sethi, S. P.; Tetrahedron Lett. 1983, 24, 5425.

31. Becker, U.; Anke, T.; Z. Naturforsch., C: J. Biosci. 1994, 49, 772 .

32. Sackton, K. L.; Dimova, N.; Zeng, X.; Tian, W.; Zhang, M.; Sackton, T. B.; Meaders, J.; Pfaff, K. L.; Sigoillot, F.; Yu, H.; Luo, X.; King, R. W.; Nature 2014, 514, 646.

33. Tiwari, A.; Riordan, J. M.; Waud, W. R.; Struck, R. F.; J. Med. Chem. 2002, 45, 1079.

34. MacMillan, J. B.; Molinski, T. F.; J. Nat. Prod. 2000, 63, 155.

35. Sitachitta, N.; Rossi, J.; Roberts, M. A.; Gerwick, W. H.; Fletcher, M. D.; Willis, C. L.; J. Am. Chem. Soc. 1998, 120, 7131.

36. Rybarczyk-Pirek, A. J.; Checinska, L.; Małecka, M.; Wojtulewski, S.; Cryst. Growth Des. 2013, 13, 3913. 
37. Flores, A. F. C.; Martins, M. J.; Frigo, L. M., Machado, P.; Campos, P. T.; Malavolta, J. L. Synth. Commun. 2012, 42, 727.

38. Flores, A. F. C.; Blanco, R. F.; Souto, A. A.; Malavolta, J. L.; Flores, D. C.; J. Braz. Chem. Soc. 2013, 24, 2059.

39. Singh, S. P.; Kumar, D.; Jones, B. G.; Threadgill, M. D.; J. Fluorine Chem. 1999, 94, 199.

40. Montoya, V.; Pons, J.; García-Antón, J.; Solans, X.; Font-Bardia, M.; Ros, J.; J. Fluorine Chem. 2007, 128, 1007.

41. Flores, A. F. C.; Piovesan, L. A.; Pizzuti, L.; Flores, D. C.; Malavolta, J. L.; Martins, M. A. P.; J. Heterocycl. Chem. 2014, 51,733 .

42. Vrbková, E.; Vyskocilová, E.; Cervený, L.; React. Kinet., Mech. Catal. 2017, 121, 307.

43. Zuo, C.; Li, C.; Ge, T.; Guo, X.; Zhang, S.; Can. J. Chem. Eng. 2017, 95, 2104.

44. Moriguchi, T.; Endo, T.; Takata, T.; J. Org. Chem. 1995, 60, 3523.

45. Bégué, J-.P.; Bonnet-Delpon, D.; Mesureur, D.; Ourévitch, M.; Magn. Reson. Chem. 1991, 29, 675.
46. Flores, A. F. C.; Brondani, S.; Zanatta, N.; Rosa, A.; Martins, M. A. P.; Tetrahedron Lett. 2002, 43, 8701.

47. Yachevskii, D. S.; Chizhov, D. L.; Pashkevich, K. I.; Charushin, V. N.; ARKIVOC 2004, 2004, 71.

48. Sloop, J. C.; Rep. Org. Chem. 2013, 3, 1.

49. El Kaim, L.; Gaultier, L., Grimaud, L.; Vieu, E.; Tetrahedron Lett. 2004, 45, 8047.

50. Flores, A. F. C.; Piovesan, L. A.; Souto, A. A.; Pereira, M. A.; Martins, M. A. P.; Balliano, T. L.; Silva, G. S.; Synth. Commun. 2013, 43, 2326.

51. Kumar, V.; Aggarwal, R.; Singh, S. P.; J. Fluorine Chem. 2006, 127,880 .

52. Sloop, J. C.; Bumgardner, C. L.; Loehle, W. D.; J. Fluorine Chem. 2002, 118, 135.

Submitted: March 29, 2019 Published online: July 15, 2019 